University of New Hampshire

University of New Hampshire Scholars' Repository

$2-27-2003$

\title{
An estimate of the stratospheric contribution to springtime tropospheric ozone maxima using TOPSE measurements and beryllium-7 simulations
}

\author{
Dale J. Allen \\ University of Maryland at College Park \\ Jack E. Dibb \\ University of New Hampshire, jack.dibb@unh.edu \\ Brian Ridley \\ NCAR \\ Kenneth E. Pickering \\ University of Maryland at College Park \\ R. Talbot \\ University of New Hampshire, robert.talbot@unh.edu
}

Follow this and additional works at: https://scholars.unh.edu/earthsci_facpub

Part of the Atmospheric Sciences Commons

\section{Recommended Citation}

Allen, D. J., J. E. Dibb, B. Ridley, K. E. Pickering, and R. W. Talbot, An estimate of the stratospheric contribution to springtime tropospheric ozone maxima using TOPSE measurements and beryllium-7 simulations, J. Geophys. Res., 108(D4), 8355, doi:10.1029/2001JD001428, 2003.

This Article is brought to you for free and open access by the Earth Sciences at University of New Hampshire Scholars' Repository. It has been accepted for inclusion in Earth Sciences Scholarship by an authorized administrator of University of New Hampshire Scholars' Repository. For more information, please contact Scholarly.Communication@unh.edu. 


\title{
An estimate of the stratospheric contribution to springtime tropospheric ozone maxima using TOPSE measurements and beryllium-7 simulations
}

\author{
Dale J. Allen, ${ }^{1}$ Jack E. Dibb, ${ }^{2}$ Brian Ridley, ${ }^{3}$ Kenneth E. Pickering, ${ }^{1}$ and Robert W. Talbot ${ }^{2}$
}

Received 26 October 2001; revised 21 May 2002; accepted 21 May 2002; published 15 January 2003.

[1] Measurements of tropospheric ozone $\left(\mathrm{O}_{3}\right)$ between $30^{\circ} \mathrm{N}$ and $70^{\circ} \mathrm{N}$ show springtime maxima at remote locations. The contribution of seasonal changes in stratospheretroposphere exchange (STE) to these maxima was investigated using measurements from the Tropospheric Ozone Production about the Spring Equinox Experiment (TOPSE) campaign and the beryllium-7 $\left({ }^{7} \mathrm{Be}\right)$ distribution from a calculation driven by fields from the Goddard Earth Observing System Data Assimilation System (GEOS DAS).

Comparison with TOPSE measurements revealed that upper tropospheric model-

calculated ${ }^{7} \mathrm{Be}$ mixing ratios were reasonable (a change from previous calculations) but that lower tropospheric mixing ratios were too low most likely due to an overestimation of scavenging. Temporal fluctuations were well captured although their amplitudes were often underestimated. Analysis of $\mathrm{O}_{3}$ measurements indicated that $\mathrm{O}_{3}$ mixing ratios increased by $5-10 \%$ month $^{-1}$ for $\theta<300 \mathrm{~K}$ (the underworld) and by $10-15 \%$ month $^{-1}$ for $\theta>300 \mathrm{~K}$ (the tropospheric middleworld). ${ }^{7} \mathrm{Be}$ mixing ratios decreased with time for $\theta<290 \mathrm{~K}$ and increased with time for $\theta>300 \mathrm{~K}$. Model-calculated middleworld increases of ${ }^{7} \mathrm{Be}$ were a factor of 2 less than measured increases. ${ }^{7} \mathrm{Be}$ with a stratospheric source (strat- ${ }^{7} \mathrm{Be}$ ) increased by $4.6-8.8 \%$ month $^{-1}$ along TOPSE flight paths within the tropospheric middleworld. Increases in strat- ${ }^{7} \mathrm{Be}$ were not seen along TOPSE flight paths in the underworld. Assuming changes in tropospheric $\mathrm{O}_{3}$ with a stratospheric source are the same as changes in strat- ${ }^{7} \mathrm{Be}$ and that $50 \%$ of $\mathrm{O}_{3}$ in the region of interest is produced in the stratosphere, changes in STE explain $20-60 \%$ of $\mathrm{O}_{3}$ increases in the tropospheric middleworld and less than $33 \%$ of $\mathrm{O}_{3}$ increases in the underworld. INDEX TERMS: 0368 Atmospheric Composition and Structure: Troposphere - constituent transport and chemistry; 3362

Meteorology and Atmospheric Dynamics: Stratosphere/troposphere interactions; 3337 Meteorology and Atmospheric Dynamics: Numerical modeling and data assimilation

Citation: Allen, D. J., J. E. Dibb, B. Ridley, K. E. Pickering, and R. W. Talbot, An estimate of the stratospheric contribution to springtime tropospheric ozone maxima using TOPSE measurements and beryllium-7 simulations, J. Geophys. Res., 108(D4), 8355, doi:10.1029/2001JD001428, 2003.

\section{Introduction}

[2] Measurements of tropospheric ozone $\left(\mathrm{O}_{3}\right)$ between $30^{\circ} \mathrm{N}$ and $70^{\circ} \mathrm{N}$ show broad summer time maxima at sites affected by pollution and springtime maxima at more remote locations [Oltmans, 1981; Logan, 1985]. The summertime maxima are attributed to rapid photochemical production of $\mathrm{O}_{3}$ during a period when ultraviolet radiation is at its peak. The springtime maxima are usually attributed to seasonal changes in the cross-tropopause transport of $\mathrm{O}_{3}$

\footnotetext{
${ }^{1}$ Department of Meteorology, University of Maryland, College Park, Maryland, USA.

${ }^{2}$ Institute for the Study of Earth, Oceans, and Space, University of New Hampshire, Durham, New Hampshire, USA.

${ }^{3}$ Atmospheric Chemistry Division, National Center for Atmospheric Research, Boulder, Colorado, USA.

Copyright 2003 by the American Geophysical Union. 0148-0227/03/2001JD001428
}

[Danielsen and Mohnen, 1977] and/or in the photochemical processing and abundance of $\mathrm{O}_{3}$ precursors [Penkett and Brice, 1986]. The relative importance of each of these factors is still unclear. Monks [2000] summarizes observations of springtime maxima and hypotheses for their cause(s) in a recent review article.

[3] An increased understanding of the processes contributing to the springtime maxima was a major goal of the Tropospheric Ozone Production about the Spring Equinox Experiment (TOPSE) (E. Atlas et al., The TOPSE experiment: Introduction, submitted to Journal of Geophysical Research, 2002). The TOPSE field experiment consisted of seven deployments and 38 science flights (TOPSE flights 5-42, flights $1-4$ were test flights) between 4 February and 23 May 2000. Each deployment began and ended at National Center for Atmospheric Research's (NCAR's) Research Aviation Facility in Broomfield, CO $\left(39^{\circ} 55^{\prime} \mathrm{N}\right.$, $\left.105^{\circ} 07^{\prime} \mathrm{W}\right)$. Each deployment included flights to Winnipeg $\left(49^{\circ} 53^{\prime} \mathrm{N}, 97^{\circ} 09^{\prime} \mathrm{W}\right)$ and Churchill, Manitoba $\left(58^{\circ} 47^{\prime} \mathrm{N}\right.$, 
$\left.94^{\circ} 12^{\prime} \mathrm{W}\right)$. Deployments 2 and $4-7$ also included flights to Thule, Greenland $\left(76^{\circ} 32^{\prime} \mathrm{N}, 68^{\circ} 45^{\prime} \mathrm{W}\right)$. Trace species and atmospheric parameters were measured on each of the NCAR C-130 flights at altitudes of up to $8 \mathrm{~km}$.

[4] In this paper, seasonal changes in the cross-tropopause transport of $\mathrm{O}_{3}$ are investigated by analyzing TOPSE measurements, Ertel's potential vorticity (PV), and output from a beryllium-7 $\left({ }^{7} \mathrm{Be}\right)$ simulation. The focus of this study is the TOPSE region (defined here to be $100^{\circ}-60^{\circ} \mathrm{W}, 40^{\circ}-$ $80^{\circ} \mathrm{N}$ ) and period (defined here to be 1 February to 31 May 2000). Past studies of seasonal variations in cross-tropopause exchange are discussed in section 2. The data and model output used in this study are described in section 3 . Model-calculated and measured ${ }^{7} \mathrm{Be}$ mixing ratios are compared in section 4. Seasonal trends in ${ }^{7} \mathrm{Be}$ and their implications for $\mathrm{O}_{3}$ are discussed in section 5. Results are summarized in section 6 .

\section{Seasonal Variations in Cross-Tropopause Exchange}

[5] The cross-tropopause net upward flux (F) of $\mathrm{O}_{3}$ during an exchange event can be calculated by subtracting the downward flux of $\mathrm{O}_{3}$ during the event from the upward flux of $\mathrm{O}_{3}$ during the event.

$$
\mathrm{F}_{\mathrm{Q}}=\mathrm{M}_{\mathrm{u}} \mathrm{Q}_{1}-\mathrm{M}_{\mathrm{d}} \mathrm{Q}_{2}
$$

where $\mathrm{M}_{\mathrm{u}}$ and $\mathrm{M}_{\mathrm{d}}$ are the upward and downward components of the mass flux during the event and $\mathrm{Q}_{1}$ and $\mathrm{Q}_{2}$ are the $\mathrm{O}_{3}$ mixing ratios in the upper troposphere and lower stratosphere, respectively. The net effect of several stratospheretroposphere exchange (STE) events on $\mathrm{O}_{3}$ is an increase in tropospheric $\mathrm{O}_{3}$ because stratospheric $\mathrm{O}_{3}$ mixing ratios exceed tropospheric mixing ratios by roughly an order of magnitude. Equation (1) can be rewritten as [e.g., Gettelman and Sobel, 2000]:

$$
\mathrm{F}_{\mathrm{Q}}=\mathrm{MQ}_{2}+\mathrm{M}_{\mathrm{u}}\left(\mathrm{Q}_{1}-\mathrm{Q}_{2}\right)
$$

where the flux is now comprised of one part equal to the net mass flux (M) multiplied by the $\mathrm{O}_{3}$ mixing ratio in the lower stratosphere and another part that is equal to the upward mass flux multiplied by the difference between upper tropospheric and lower stratospheric $\mathrm{O}_{3}$ mixing ratios. Assuming $\mathrm{M}_{\mathrm{u}}$ is zero, a defendable assumption in the middle stratosphere, the cross-tropopause flux of $\mathrm{O}_{3}$, can be computed as a residual of the $\mathrm{O}_{3}$ budget in the region between the tropopause and the middle stratosphere [e.g., Gettelman and Sobel, 2000].

[6] The net mass flux across the tropopause is determined by the frequency of STE events and the strength of the wave-driven and turbulence-driven Brewer-Dobson circulation [Brewer, 1949; Dobson, 1956]. This diabatic circulation consists of upward motion in the tropics and descending motion at higher latitudes (Figure 1). Its connection with STE can be understood by dividing the atmosphere into three parts, the underworld, middleworld, and overworld [Hoskins, 1991; Holton et al., 1995]. The underworld and overworld are the regions of the atmosphere nearest and farthest from the Earth, respectively. Isentropes within these regions do not cross the tropopause.

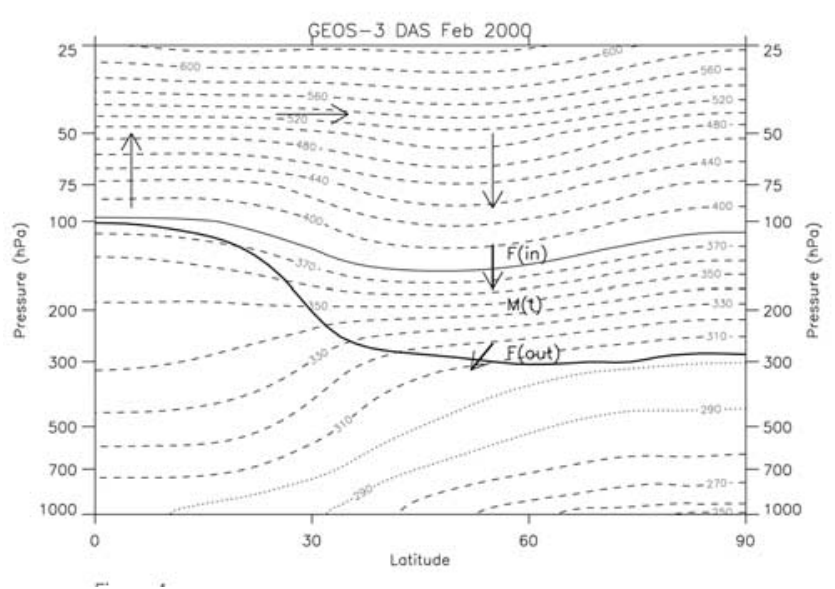

Figure 1. Zonally averaged mean (February 2000) $\theta$ (thin lines) and tropopause pressure (thick solid line) from the GEOS-3 DAS. Contour interval is $10(20) \mathrm{K}$ for $\theta<(>) 380 \mathrm{~K}$. The $380 \mathrm{~K}$ isentrope is shown with a thin solid line. The 290 and $300 \mathrm{~K}$ isentropes are shown with dotted lines. M(t) denotes the mass of the lowermost stratosphere (upper middleworld), the region between the tropopause and the $380 \mathrm{~K}$ isentrope. $\mathrm{F}(\mathrm{in})$ denotes the flux into the upper middleworld from the overworld. F(out) denotes the flux from the upper to lower middleworlds (i.e., the net stratosphere-to-troposphere exchange). Notation and concept from the study of Appenzeller et al. [1996].

In the absence of diabatic processes, air cannot move between the underworld and overworld. The remaining portion of the atmosphere is called the middleworld. Isentropes in this region, which has an upper bound at $\sim 380 \mathrm{~K}$, intersect the tropopause. Therefore, it includes portions of the upper troposphere and extratropical lower stratosphere. Seasonal variations in the strength of the Brewer-Dobson circulation lead to seasonal variations in the downward transport of mass between the stratospheric overworld and middleworld [Holton, 1990]. This downward transport is important because mass in the stratospheric middleworld can be transported isentropically into the troposphere.

\subsection{Estimates of STE From Meteorological Data}

[7] Appenzeller et al. [1996] studied seasonal variations in transport between the stratospheric overworld and middleworld and in STE using United Kingdom Meteorological Office (UKMO) stratospheric analyses. They found that transport between the stratospheric overworld and middleworld has a maximum in early winter and a minimum in late spring or early summer. Gettelman and Sobel [2000] found a similar seasonal cycle using fields from version 1 of the Goddard Earth Observation System Data Assimilation System (GEOS-1 DAS). By continuity, the net flux ( $\left.\mathrm{F}_{\text {out }}\right)$ across the tropopause can be calculated by subtracting the change in the mass of the stratospheric middleworld with time $(\mathrm{dM} /$ $\mathrm{dt}$ ) from the net flux into the stratospheric middleworld from above $\left(\mathrm{F}_{\text {in }}(\mathrm{t})\right)$ where $\mathrm{F}_{\text {in }}(\mathrm{t})$ and $\mathrm{F}_{\text {out }}(\mathrm{t})$ are defined to be positive for downward directed mass fluxes (see Figure 1) [Appenzeller et al., 1996].

$$
\mathrm{F}_{\text {out }}(\mathrm{t})=\mathrm{F}_{\text {in }}(\mathrm{t})-\mathrm{dM} / \mathrm{dt}
$$


The seasonal cycle of STE is not completely determined by the seasonal cycle in the residual circulation because seasonal changes in the position of the tropopause lead to changes in the mass of the stratospheric middleworld. The tropopause moves upward and poleward during the transition from winter to summer and downward and equatorward during the transition from summer to winter [Staley, 1982]. The result is a net transport of mass from the stratospheric to the tropospheric middleworld during the spring and a net transport of mass from the tropospheric to the stratospheric middleworld during the fall. Appenzeller et al. [1996] found that the net downward transport across the tropopause is large and increasing slowly (by 10-20\%) between December and June. A broad peak exists because springtime decreases in inflow from the overworld are offset by springtime decreases in the mass of the stratospheric middleworld. Gettelman and Sobel [2000] found an earlier (late winter) and more defined peak in downward transport across the tropopause when they calculated STE using the Wei method [Wei, 1987].

[8] Cross-tropopause transport is of the most interest when it results in the irreversible transport of material between stratosphere and troposphere. Irreversible STE in the extratropics occurs primarily by small-scale mixing within tropopause folds [Danielsen, 1968], cutoff lows [Bamber et al., 1984], and planetary-scale anticyclones [Chen, 1995]. Seasonal cycles in the frequency and/or intensity of any of these features can lead to seasonal changes in STE. Folding events are more than twice as common as cutoff lows [Ebel et al., 1996]. They also show clear seasonal cycle with a minimum in the summer and a broad peak between midautumn and midspring [Ebel et al., 1996; Elbern et al., 1998]. Cutoff low events show a slight preference for the summer [Price and Vaughan, 1992].

[9] Wernli and Bourqui [2002] quantified seasonal and latitudinal variations in extratropical STE by examining European Center for Medium Range Weather Forecasting (ECMWF)-based air trajectories that cross the $2.0 \times 10^{-6} \mathrm{~K}$ $\mathrm{m}^{2} \mathrm{~kg}^{-1} \mathrm{~s}^{-1}$ PV (2.0 PVU) surface, the "traditional" dynamical tropopause [Holton et al., 1995]. They found that net exchange was downward throughout the year in the midlatitudes. The amplitude of the downward exchange was largest between January and April and smallest between August and October. At higher latitudes $\left(65^{\circ}-90^{\circ} \mathrm{N}\right)$, the net exchange was slightly upward and did not vary significantly with season. In the vertical, STE was largest in a 150 $\mathrm{hPa}$ layer below the climatological tropopause. This layer corresponds to approximately $285-320 \mathrm{~K}$ in the winter and $310-340 \mathrm{~K}$ in the summer. Seasonal variations in tropopause height are at least partially responsible for differing seasonal cycles between the lower and upper portions of the middleworld. Analyses of ECMWF fields show vigorous exchange throughout the year in the lower middleworld $(\theta<$ $330 \mathrm{~K})$ [Chen, 1995] and a summertime peak in exchange in the upper middleworld [Chen, 1995; Postel and Hitchman, 1999].

\subsection{Estimates Derived From Model-Calculated and Measured Radionuclide Distributions}

[10] Seasonal changes in the cross-tropopause flux of $\mathrm{O}_{3}$ can also be estimated through the analysis of radionuclide distributions. Radionuclides that can act as stratospheric tracers include strontium-90 $\left({ }^{90} \mathrm{Sr}\right)$ and the isotopes ${ }^{7} \mathrm{Be}$ and ${ }^{10} \mathrm{Be}$ [Husain et al., 1977; Dutkiewicz and Husain, 1985]. Typical stratospheric mixing ratios of these species exceed tropospheric mixing ratios by over an order of magnitude. ${ }^{90} \mathrm{Sr}$ is a species with a 39.9-year lifetime (mean life with respect to radioactive decay) that is produced by nuclear detonations. ${ }^{7} \mathrm{Be}$ is a species with a 76 day lifetime that is produced by cosmic radiation, while ${ }^{10} \mathrm{Be}$ is a species with a 3.6 million year lifetime that is produced by cosmic radiation. Danielsen and Mohnen [1977] studied seasonal variations in STE using seasonal variations in the ${ }^{90} \mathrm{Sr}$ deposition rate and observed relationships between ${ }^{90} \mathrm{Sr}, \mathrm{PV}$, and $\mathrm{O}_{3}$. Their analysis indicated that the net transport of mass between stratosphere and troposphere peaked during midMay. Fitting a cosine to the seasonal variation, they estimated that exchange rates of mass $\left(\mathrm{O}_{3}\right)$ during mid-May exceeded exchange rates during mid-November by a factor of 3.0 (4.8) while exchange rates of mass $\left(\mathrm{O}_{3}\right)$ during midMay exceeded exchange rates during mid-January by a factor of 2.0 (2.8).

[11] The interpretation of seasonal peaks in radionuclide data is complicated because a balance between four processes (STE, vertical and horizontal mixing within the troposphere, and scavenging) controls seasonal variations in tropospheric radionuclide mixing ratios [Feely et al., 1989]. The relative importance of each of these processes depends on location and season. For example, analysis of ${ }^{7} \mathrm{Be},{ }^{10} \mathrm{Be}$, and ${ }^{210} \mathrm{~Pb}$ (a species with a 32.3 -year lifetime that is produced predominantly in the troposphere by the decay of Radon-222) aerosol samples taken at Alert, Northwest Territories, Canada indicates that seasonal variations in vertical mixing within the troposphere are the main factor responsible for springtime peaks in ${ }^{7} \mathrm{Be}$ and ${ }^{10} \mathrm{Be}$ at that location [Dibb et al., 1994].

[12] Chemistry and transport model (CTM) calculations aid in the interpretation of radionuclide data. Rehfeld and Heimann [1995] studied seasonal changes in the intensity of the meridional circulation and STE by comparing modelcalculated and observed mixing ratios of ${ }^{90} \mathrm{Sr},{ }^{7} \mathrm{Be}$, and ${ }^{10} \mathrm{Be}$. They found that seasonal changes in scavenging and STE contribute to seasonal changes in ${ }^{7} \mathrm{Be}$. However, seasonal changes in the ${ }^{10} \mathrm{Be} /{ }^{7} \mathrm{Be}$ ratio were dominated by seasonal changes in STE. The ${ }^{10} \mathrm{Be} /{ }^{7} \mathrm{Be}$ ratio in the upper troposphere peaked during February and March indicating that STE peaked during this period. The ratio in the lower troposphere peaked during March and April indicating that it takes about a month to mix air from the upper to lower troposphere. Synoptic conditions following STE are often conducive to large-scale subsidence that transports tracers from the upper to the lower troposphere [Moody et al., 1996; Cooper et al., 1998].

[13] Koch and Rind [1998] evaluated the intensity of the meridional circulation in the lower stratosphere using output from simulations of ${ }^{7} \mathrm{Be}$ and ${ }^{10} \mathrm{Be}$ with the Goddard Institute for Space Studies (GISS) GCM. They found that the net transport is poleward and vigorous during the winter and spring and equatorward and weak during the summer. Koch et al. [1996] evaluated processes affecting the vertical mixing of tracers in the troposphere using output from ${ }^{7} \mathrm{Be}$ and ${ }^{210} \mathrm{~Pb}$ simulations. They found that seasonal changes in middle and upper tropospheric mixing are affected by seasonal changes in the strength of the meri- 
dional circulation. However, transport to the surface is more closely related to seasonal changes in convective mixing.

\subsection{Estimates Derived From Model-Calculated and Measured $\mathrm{O}_{3}$ Distributions}

[14] Seasonal changes in the cross-tropopause flux of $\mathrm{O}_{3}$ have also been estimated through the analysis of meteorological parameters, $\mathrm{O}_{3}$ measurements and/or model output. M. A. Olsen et al. (Estimating downward cross-tropopause ozone flux using column ozone and potential vorticity, submitted to Journal of Geophysical Research, 2002) estimated the net downward flux of $\mathrm{O}_{3}$ across the Northern Hemisphere midlatitude tropopause using the relationship between total column $\mathrm{O}_{3}$ and $\mathrm{PV}$. They found that exchange rates in mid-April exceeded exchange rates in mid-September by a factor of 2 . Exchange rates increased by $\sim 25 \%$ between mid-January and mid-April. They attributed the seasonal cycle to seasonal changes in the frequency and strength of baroclinic systems.

[15] Roelofs and Lelieveld [1997] studied seasonal changes in Northern Hemisphere STE of $\mathrm{O}_{3}$ using a GCM, the European Center Hamburg Model, version 4 (ECHAM4), coupled to a tropospheric chemistry model. They found that transport of stratospheric $\mathrm{O}_{3}$ into the troposphere increased by nearly $20 \%$ between winter and spring. However, the winter to spring increase due to transport was less than the winter to spring increase in photochemically produced $\mathrm{O}_{3}$. Wang et al. [1998] studied the causes of springtime $\mathrm{O}_{3}$ maxima using a CTM driven by fields from the GISS GCM. They attributed springtime maxima to the "superimposed" contributions of $\mathrm{O}_{3}$ transported from the stratosphere that peaked in the early spring, and $\mathrm{O}_{3}$ produced in the troposphere that peaked in the late spring.

\subsection{Summary}

[16] Seasonal variations in the cross-tropopause flux of $\mathrm{O}_{3}$ have been studied by a variety of independent methods. With few exceptions, a springtime peak is seen in STE. The contribution of this springtime peak in STE to the springtime $\mathrm{O}_{3}$ maxima is the focus of this study.

\section{Data and Model Description}

[17] The contribution of STE to the springtime $\mathrm{O}_{3}$ maxima will be investigated using meteorological parameters derived from the GEOS-3 DAS [Schubert et al., 1993; Bloom et al., 1996], measurements from the TOPSE campaign, and the ${ }^{7} \mathrm{Be}$ distribution from a CTM calculation. These tools are discussed in the following sections.

\subsection{University of Maryland (UMD) CTM/GEOS-3 DAS}

[18] The distribution of ${ }^{7} \mathrm{Be}$ was simulated using the UMD-CTM, a version of the Goddard CTM [Allen et al., 1996a, 1996b] that includes wet scavenging and dry deposition. The calculations were driven by data from the GEOS-3 DAS. The mixing ratio change due to advection is calculated using a multidimensional and semi-Lagrangian extension of the piecewise parabolic method (PPM) [ Lin and Rood, 1996]. Convective mixing in the UMD-CTM [Allen et al., 1996b] is calculated using cumulus mass flux and detrainment output from the Relaxed Arakawa-Schu- bert (RAS) algorithm [Arakawa and Schubert, 1974; Moorthi and Suarez, 1992] that is used to parameterize convection in the GEOS GCM. Three-hour-averaged planetary boundary layer depths are available from the GEOS-3 DAS. Turbulent mixing within the boundary layer is parameterized using a fractional mixing scheme [Allen et al., 1996a]. Dry deposition is parameterized based on surface type [e.g., Brasseur et al., 1998] with deposition velocities from the study of Sander and Crutzen [1996]. Wet removal of soluble species is accomplished through a wet scavenging algorithm described by Chin et al. [2000] using precipitation rates from the GEOS-3 DAS. Scavenging by cirrus precipitation [Lawrence and Crutzen, 1998; Liu et al., 2001] is not included.

[19] Data from the GEOS-3 DAS are archived on a 48 sigma layer $1^{\circ}$ in latitude by $1^{\circ}$ in longitude $\left(1^{\circ} \times 1^{\circ}\right)$ grid. The UMD-CTM was run at a $2^{\circ} \times 2.5^{\circ}$ resolution with 35 sigma-pressure layers. The model tops of the GEOS-3 DAS and the UMD-CTM are $0.01 \mathrm{hPa}$. Pressures at the tops and bottoms of the first 25 GEOS-3 DAS and UMDCTM layers $(\sim 1000$ to $\sim 37.6 \mathrm{hPa})$ are identical. The uppermost 23 GEOS-3 DAS layers are mapped onto 10 UMD-CTM layers. The resulting fields are mapped onto a $2^{\circ} \times 2.5^{\circ}$ grid. The UMD-CTM grid includes 8 layers between the surface and $850 \mathrm{hPa}$ and 13 layers between 850 and $100 \mathrm{hPa}$ with a vertical resolution in the expected TOPSE tropopause region of $1.4-1.8 \mathrm{~km}$. The sigmapressure interface of the UMD-CTM is $\sim 242 \mathrm{hPa}$. Sixhour-averaged $u$ and $v$ components of the wind are taken from the GEOS-3 DAS. The winds are interpolated in time to the transport time. The vertical velocity is calculated kinematically each transport time step (15 $\mathrm{min}$ ) by assuming the vertical velocity is zero at the top of the model and integrating downward.

[20] Ertel's PV was calculated on the UMD CTM grid using fields from the GEOS-3 DAS. The formula for PV can be expressed in the form [e.g., Nash et al., 1996]:

$$
\mathrm{PV}=-\mathrm{g}\left(\zeta_{\sigma}+\mathrm{f}\right) \partial \theta / \partial \mathrm{p}
$$

where $\mathrm{g}$ is the acceleration due to gravity, $\zeta_{\sigma}$ is the vertical component of the relative vorticity on a sigma surface, $\mathrm{f}$ is the Coriolis parameter, $\theta$ is the potential temperature, and $\mathrm{p}$ is the pressure. The $\zeta_{\sigma}$ is given by

$$
\zeta_{\sigma}=\partial v / \partial x-\partial u / \partial y
$$

where $u$ and $v$ are the zonal and meridional wind components along the $x$ and $y$ Cartesian coordinates. Wind components are available at 00, 06, 12, and 18 UT. PV was calculated for every 6-hour period between 1 February and 31 May 2000.

[21] The tropopause pressure was also calculated as a function of latitude and longitude on the UMD-CTM grid. It was defined to be the largest pressure (pressure $<600 \mathrm{hPa}$ ) at which Ertel's PV equaled 2.5 PVU. However, if the resulting tropopause pressure was less than the pressure at the $380 \mathrm{~K}$ surface, the pressure at the $380 \mathrm{~K}$ surface was used as the tropopause pressure. Estimates of PV at the midlatitude tropopause vary from $1.5[\mathrm{WMO}, 1996]$ to 3.5 [Hoerling et al., 1991] PVU. A value of 2.5 PVU was chosen as a compromise between these values. The impact on strato- 
sphere-to-troposphere and troposphere-to-stratosphere exchange of varying the tropopause definition (from 1 to 4.5 PVU) is discussed by Morgenstern and Carver [2001].

\section{2. ${ }^{7} \mathrm{Be}$ and $\mathrm{O}_{3}$ Data}

[22] Dibb et al. [2002] describe the procedure used to determine ${ }^{7} \mathrm{Be}$ activities during the TOPSE mission. Atmospheric aerosol samples were collected on filters during $12-$ 24 min constant altitude sampling periods. The filters were shipped to a laboratory and analyzed for ${ }^{7} \mathrm{Be}$ activity using gamma spectroscopy. Activities were adjusted for loss by decay during the time period between sampling and analysis.

[23] Two hundred and ninety eight aerosol samples were collected on 31 different days during TOPSE flights 5-42. Three of the samples were taken in the stratosphere (PV $>$ 2.5; mean sampling pressure $<$ tropopause pressure). Of the remaining 295, eight had mean sampling pressures within $10 \mathrm{hPa}$ of the tropopause pressure. These eight samples included four samples from deployment $5 .{ }^{7} \mathrm{Be}$ mixing ratios (see appendix) from 239 samples exceeded detection limits $\left(0.8-4.5\right.$ milli-Becquerels $\left.(\mathrm{mBq}) \mathrm{SCM}^{-1}\right)$, which varied with sampling pressure and time. Mixing ratios less than the detection limit were set to the detection limit. This step introduced a positive bias of $0.0-0.4 \mathrm{mBq} \mathrm{SCM}^{-1}$ $(0.0-1.8 \%)$ in the mean ${ }^{7} \mathrm{Be}$ mixing ratio (The mean ${ }^{7} \mathrm{Be}$ mixing ratio decreased from 19.9 to $19.5 \mathrm{mBq} \mathrm{SCM}^{-1}$ when the mixing ratios at these points were set to zero). The median and maximum mixing ratios during the TOPSE mission were 11.4 and $175 \mathrm{mBq} \mathrm{SCM}^{-1}$, respectively. The standard deviation was $26.7 \mathrm{mBq} \mathrm{SCM}^{-1}$.

[24] $\mathrm{O}_{3}$ measurements were collected using the NCAR Atmospheric Chemistry Division (ACD) fast chemiluminescence instrument [Ridley et al., 2002]. $\mathrm{HNO}_{3}$ measurements were taken using a mist chamber sampling technique and ion chromatographic analysis [Talbot et al., 1999] (E. Scheuer et al., Seasonal distributions of fine aerosol sulfate in the North American Arctic basin during TOPSE, submitted to Journal of Geophysical Research, 2002). Fiveminute average $\mathrm{O}_{3}$ and $\mathrm{HNO}_{3}$ mixing ratios from these measurements are available as part of the 300-s TOPSE data merges that are available through the NCAR ACD. Mean $\mathrm{O}_{3}$ and $\mathrm{HNO}_{3}$ mixing ratios for the 12-24 min aerosol sampling periods were calculated by averaging data from the 5-min merges over the aerosol sampling periods.

[25] The effect of seasonal trends in STE on seasonal trends in $\mathrm{O}_{3}$ and ${ }^{7} \mathrm{Be}$ in the troposphere are evaluated in section 5. Aerosol samples collected below $1 \mathrm{~km}$ or above the tropopause are not included in the trend analysis. Surface layer samples are excluded in order to remove "trends" associated with bromine chemistry over ice-covered surfaces [Barrie et al., 1988]. Twenty-one samples (three, one, three, six, seven, zero, and one from deployments $1-7$, respectively) were collected below $1 \mathrm{~km}$. Three stratospheric samples (two from deployment 3 and one from deployment 5) were also removed. The total number of samples used for the correlation and trend analysis in section 5 is 274 .

\section{3. ${ }^{7}$ Be Calculations}

[26] ${ }^{7} \mathrm{Be}$ is produced when neutrons created by collisions between primary cosmic rays and atoms collide with nitrogen and oxygen atoms. Since cosmic rays follow the Earth's magnetic field, ${ }^{7} \mathrm{Be}$ production is largest at latitudes pole-

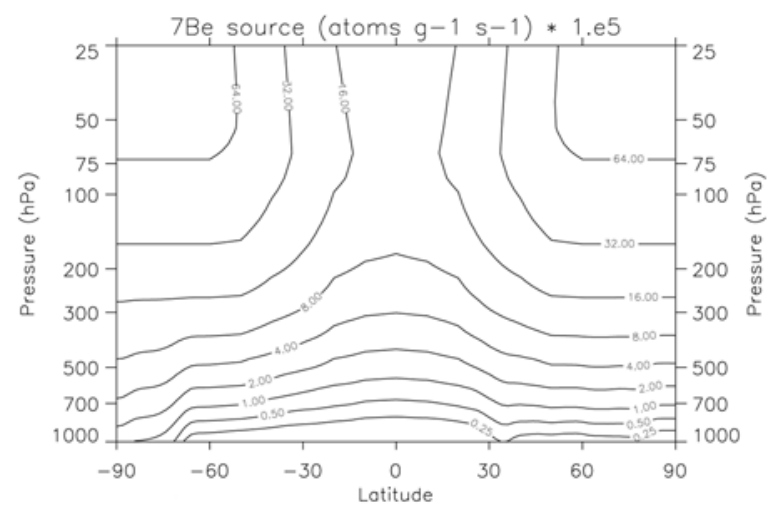

Figure 2. ${ }^{7} \mathrm{Be}$ source (atoms $\mathrm{g}^{-1} \mathrm{~s}^{-1} * 1 . \mathrm{e}-5$ ) as a function of latitude and pressure.

ward of $60^{\circ}$. In the vertical, production is largest in the lower stratosphere. ${ }^{7}$ Be production also varies with the solar cycle. It is smallest when the solar cycle is near its maximum and largest when the cycle is near its minimum. The solar cycle was near its maximum in 2000 . The ${ }^{7} \mathrm{Be}$ source used in this study is given by Lal and Peters [1967]. The magnitude of the source, 0.080 atoms ${ }^{7} \mathrm{Be}{ }^{-2} \mathrm{~s}^{-1}$, is appropriate for a solar maximum year. The ${ }^{7} \mathrm{Be}$ source used in this study is shown as a function of latitude and pressure in Figure 2.

[27] It is important to note that ${ }^{7} \mathrm{Be}$ has a significant tropospheric source. Therefore, in order to study STE using ${ }^{7} \mathrm{Be}$, it is desirable to solve for the distribution of ${ }^{7} \mathrm{Be}$ with a tropospheric source (trop- ${ }^{7} \mathrm{Be}$ ) separately from ${ }^{7} \mathrm{Be}$ with a stratospheric source (strat- ${ }^{7} \mathrm{Be}$ ) [e.g., Liu et al., 2001]. This was achieved by dividing the ${ }^{7} \mathrm{Be}$ source into stratospheric and tropospheric components using the tropopause pressure. Separate calculations for tropospheric and stratospheric ${ }^{7} \mathrm{Be}$ began 1 January 2000 following a 6-month spin up from an initial condition of ${ }^{7} \mathrm{Be}=0$ using GEOS-3 DAS fields for July-December 2000. The spin up did not use data from 1999 because the GEOS-3 assimilation did not begin until November 1999.

[28] Time-averaged (1 February to 31 May 2000) budgets for trop- ${ }^{7} \mathrm{Be}$ and strat- ${ }^{7} \mathrm{Be}$ are shown for the globe and the TOPSE region $\left(100^{\circ}-60^{\circ} \mathrm{W}, 40^{\circ}-80^{\circ} \mathrm{N}\right)$ in Table 1 . Overall, seventy-one percent of model-calculated ${ }^{7} \mathrm{Be}$ is produced in the stratosphere. This value agrees remarkably well with the value $(70 \%)$ given by Lal [1963] and Lal and Peters [1967]. The extremely good agreement is partially fortuitous given uncertainties in the source distribution and the tropopause location. Radioactive decay is the dominant loss mechanism for ${ }^{7} \mathrm{Be}$ with a stratospheric source (strat- ${ }^{7} \mathrm{Be}$ ), while wet scavenging is the dominant loss mechanism for ${ }^{7} \mathrm{Be}$ with a tropospheric source (trop- ${ }^{7} \mathrm{Be}$ ). Dry deposition plays a relatively minor role. Within the TOPSE region, because of the relatively low tropopause, strat $-{ }^{7} \mathrm{Be}$ accounts for $84 \%$ of the total ${ }^{7} \mathrm{Be}$ production. The relative importance of radioactive decay is also enhanced due to low scavenging rates over the northern portion of the TOPSE region.

[29] The zonally averaged model-calculated ${ }^{7} \mathrm{Be}$ distribution in $\mathrm{mBq} \mathrm{SCM}{ }^{-1}$ (see appendix) and its stratospheric component (strat- ${ }^{7} \mathrm{Be} /$ total $-{ }^{7} \mathrm{Be}$ ) are shown for the TOPSE 
Table 1. Monthly Average Global and TOPSE Region $\left(100^{\circ}-\right.$ $\left.60^{\circ} \mathrm{W}, 40^{\circ}-80^{\circ} \mathrm{N}\right){ }^{7} \mathrm{Be}$ Budget for Trop- ${ }^{7} \mathrm{Be}$ and Strat $^{7} \mathrm{Be}^{\mathrm{a}}$

\begin{tabular}{|c|c|c|c|c|}
\hline & \multicolumn{2}{|c|}{ Trop- ${ }^{7} \mathrm{Be}$} & \multicolumn{2}{|c|}{ Strat- ${ }^{7} \mathrm{Be}$} \\
\hline & Mass & Loss $(\%)$ & Mass & Loss $(\%)$ \\
\hline \multicolumn{5}{|c|}{ Global Budget } \\
\hline Source & 3.61 & & 8.69 & \\
\hline Decay & 0.90 & 24.6 & 6.75 & 81.6 \\
\hline Wet dep & 2.63 & 72.3 & 1.45 & 17.6 \\
\hline Dry dep & 0.11 & 3.1 & 0.07 & 0.9 \\
\hline Total & 3.64 & 100.0 & 8.27 & 100.0 \\
\hline \multicolumn{5}{|c|}{ TOPSE Region Budget } \\
\hline Source & 0.065 & & 0.355 & \\
\hline Decay & 0.018 & 35.4 & 0.251 & 90.9 \\
\hline Wet dep & 0.029 & 58.4 & 0.023 & 8.5 \\
\hline Dry dep & 0.003 & 6.2 & 0.002 & 0.6 \\
\hline Total & 0.050 & 100.0 & 0.276 & 100.0 \\
\hline
\end{tabular}

${ }^{\text {a }}$ The magnitude of the ${ }^{7} \mathrm{Be}$ source and its sinks is given in the mass column $\left(\mathrm{g} \mathrm{month}^{-1}\right)$. The percent each loss term contributes to the total loss is shown in the loss column.

period in Figures 3a and 3b. As expected, stratospheric mixing ratios exceed tropospheric mixing ratios by an order of magnitude. At a given pressure within the troposphere, mixing ratios are largest in the descending branches of the Hadley circulation and lowest at latitudes where scavenging is large. In general, model-calculated mixing ratios and stratospheric components are very similar to values shown by Liu et al. [2001] for a ${ }^{7} \mathrm{Be}$ simulation without cirrus scavenging. The stratospheric component in the troposphere varies from $15 \%$ to $80 \%$. As expected, low values are seen in regions of ascent such as the tropics while high values are seen in regions of subsidence such as the subtropics.

\section{Comparison of Model-Calculated and Observed ${ }^{7} \mathrm{Be}$}

\subsection{Individual Flights}

[30] Model-calculated and observed ${ }^{7} \mathrm{Be}$ mixing ratios during flights 12 (25 February), 16 (7 March), 28 (7 April),
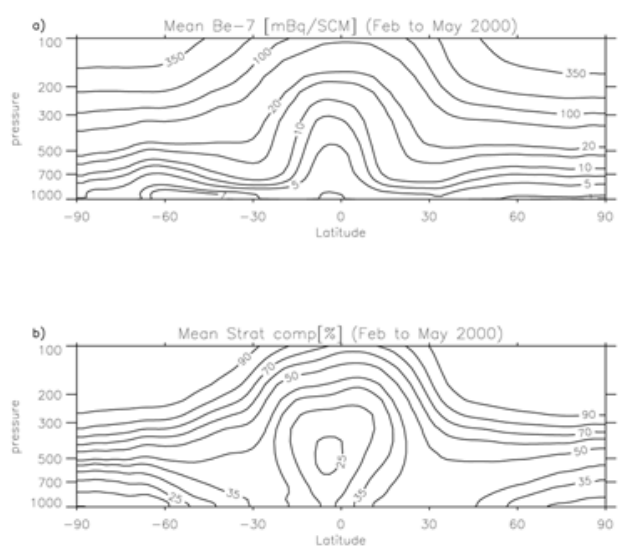

Figure 3. Zonally averaged mean (1 February to 31 May 2000) model-calculated ${ }^{7} \mathrm{Be}$ as a function of latitude and pressure. (a) Mixing ratio in units of 1, 2, 5, 7.5, 10, 15, 20, $50,100,200$, and $350 \mathrm{mBq} \mathrm{SCM}^{-1}$ and (b) Percent with a stratospheric source. Contour intervals of $20 \%, 25 \%, 30 \%$, $35 \%, 40 \%, 50 \%, 60 \%, 70 \%, 80 \%$, and $90 \%$.
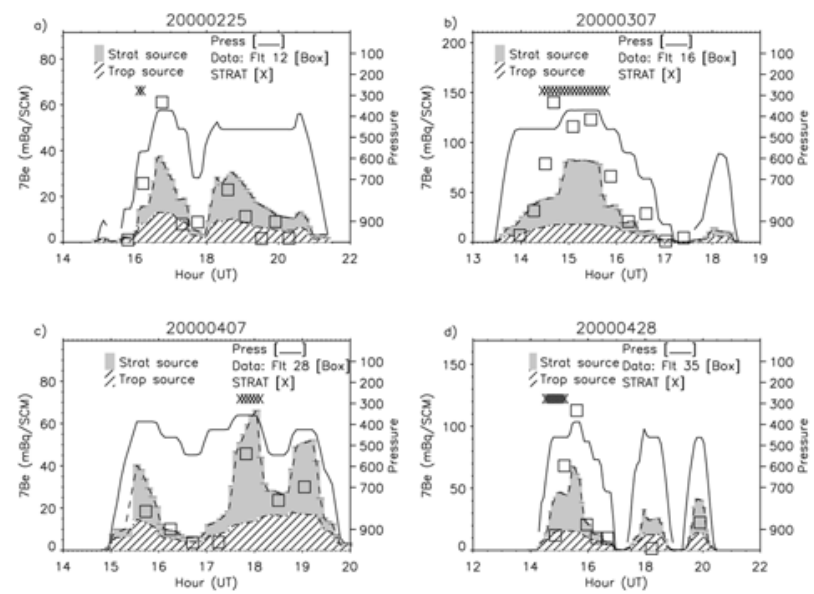

Figure 4. Model-calculated versus measured ${ }^{7} \mathrm{Be}$ on (a) 25 February, (b) 7 March, (c) 7 April, and (d) 28 April. Measured mixing ratios are shown with boxes. The hatched (shaded) region shows the contribution of model-calculated ${ }^{7} \mathrm{Be}$ with a tropospheric (stratospheric) source. A solid line shows the mean sampling pressure. Time periods when stratospheric influence is believed to be large are shown with an X.

and 35 (28 April) are compared in Figures $4 a-4 d$ and 5a$5 \mathrm{~d}$. These flights were chosen because more than changes in pressure controlled ${ }^{7} \mathrm{Be}$ variations during these flights. The 25 February, 7 April, and 28 April flights originated in Thule and ended in Churchill. The 7 March flight began and ended in Churchill. In general, model-calculated and observed ${ }^{7} \mathrm{Be}$ mixing ratios track well. Within each flight, mixing ratios show a strong dependence on pressure; although considerable variation is also seen during several constant altitude segments (e.g., 18-21 UT, 25 February and 14-15 UT, 7 March). The model does a reasonable job

\section{UMD/GEOS $-37 \mathrm{Be}(2 \times 2.5$ UG)}
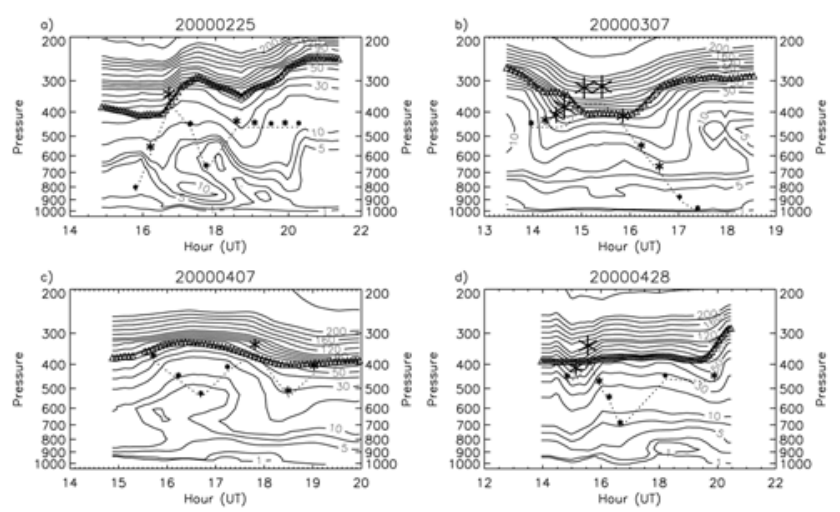

Figure 5. Curtain plots comparing model-calculated ${ }^{7} \mathrm{Be}$ mixing ratios above and below the flight paths. Measured mixing ratios are proportional to asterisk size and range from 0.9 to $113.0 \mathrm{mBq} \mathrm{SCM}^{-1}$. The lowest points on each of the asterisks give sampling pressures. Dates shown are (a) 25 February, (b) 7 March, (c) 7 April, and (d) 28 April. The location of the tropopause is shown with triangles. 


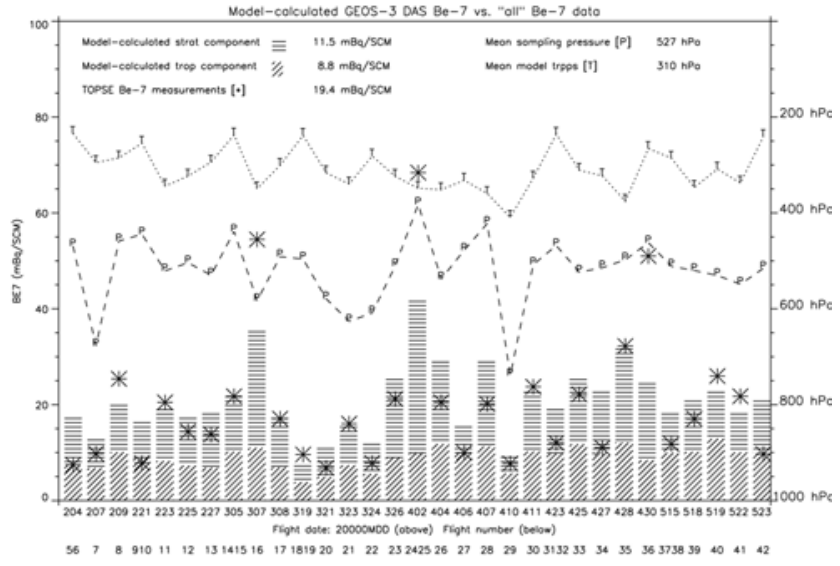

Figure 6. Model-calculated versus measured ${ }^{7} \mathrm{Be}$ mixing ratio as a function of flight date. The component of modelcalculated ${ }^{7} \mathrm{Be}$ with a tropospheric (stratospheric) source is shown with diagonal (horizontal) lines. The mean sampling pressure of the aircraft is shown with "P's." The mean tropopause pressure is shown with "T's."

of capturing this constant altitude variation. Periods when analysis of temporal fluctuations in ${ }^{7} \mathrm{Be}, \mathrm{O}_{3}$, and $\mathrm{HNO}_{3}$ data indicated that stratospheric influence was large are shown with X's [Dibb et al., 2002]. Both model-calculated and observed mixing ratios are enhanced during these periods; although, model-calculated mixing ratios are usually too low. The underestimation of variability is not surprising. Model-calculated mixing ratios were obtained by interpolating $2^{\circ} \times 2.5^{\circ}$ model output at $00,06,12$, and 18 UT to the measurement location and time. Sampling periods were only 12-24 min, which translates to $75-150 \mathrm{~km}(1 / 2-1$ grid box) at typical C-130 speeds.

[31] Curtain plots for each of the four flights are shown in Figures $5 \mathrm{a}-5 \mathrm{~d}$. The location of the GEOS-3 DAS tropopause is shown by triangles. Lower stratospheric mixing ratios exceed upper tropospheric mixing ratios by approximately an order of magnitude. Clearly, the model is able to maintain large gradients across the tropopause. Comparison of ${ }^{7} \mathrm{Be}$ measurements and model output indicates that the location of tropopause folds is reasonably well simulated by the model.

\subsection{Mean Distributions}

[32] Mean measured and model-calculated ${ }^{7} \mathrm{Be}$ mixing ratios, tropopause pressures, and sampling pressures are shown as a function of flight date in Figure 6. Mean values for each date were calculated by weighting individual measurements and model values at the sampling locations by sampling lengths. Overall, mean model-calculated and measured mixing ratios differ by only $5 \%$.

[33] Observed daily average ${ }^{7} \mathrm{Be}$ mixing ratios exceed 30 $\mathrm{mBq} \mathrm{SCM}{ }^{-1}$ on 7 March, 2 April, 28 April, and 30 April. Mean mixing ratios are high on these days because several of the individual measurements were taken at relatively low pressures and/or within tropopause folds (e.g., 7 March (see Figure 5b), 2 April (not shown), and 28 April (see Figure 5d)). Model-calculated mean mixing ratios on these days are also much larger than normal. In general, model-calculated ${ }^{7} \mathrm{Be}$ mixing ratios are too low within tropopause folds. The low bias may be caused by the relatively coarse resolution of the model or by errors in the source specification. ${ }^{7} \mathrm{Be}$ mixing ratios increase rapidly with height in the lower stratosphere. Therefore, small errors in the source distribution could lead to significant errors in mixing ratios. The ability of the CTM to capture the location and time of high ${ }^{7} \mathrm{Be}$ mixing ratios is encouraging. It suggests that the location and time of major STE events are reasonably well simulated by the UMD-CTM when driven by GEOS-3 DAS fields.

[34] Mean model-calculated and observed ${ }^{7} \mathrm{Be}$ profiles in the southern (latitudes $<60^{\circ} \mathrm{N}$ ) and northern (latitudes $>$ $60^{\circ}$ ) portions of the TOPSE region are shown in Figures 7a and $7 \mathrm{~b}$, respectively. In general, model-calculated mixing ratios are too low in the lower troposphere and slightly high in the upper troposphere. The low bias is most noticeable in the southern portion of the TOPSE region where mixing ratios in the lowest troposphere are too low by almost a factor of 2. An upper tropospheric high bias of $10-30 \%$ is evident in the northern portion of the TOPSE region. Model-calculated upper tropospheric mixing ratios in the southern portion of the TOPSE region appear to be reasonable given the large variability of observed mixing ratios in the upper troposphere.

[35] The low bias in the lower troposphere may be caused by an overestimation of wet scavenging within stratiform clouds. Scavenging rates within stratiform clouds are proportional to the precipitation rate and inversely proportional to the liquid water content [Giorgi and Chameides, 1986]. Monthly average GEOS-3 DAS precipitation rates for the $100^{\circ}-60^{\circ} \mathrm{W}, 30^{\circ}-60^{\circ} \mathrm{N}$ region during the TOPSE period differ from satellite-gauge precipitation estimates from the Global Precipitation Climatology Project Version 2 Combined Precipitation Data Set [Huffman et al., 1995; Susskind et al., 1997] by less than $20 \%$. In this study, a cloud condensed water content of $0.5 \times 10^{-3} \mathrm{~kg} \mathrm{~m}^{-3}$ [Giorgi and Chameides, 1986] was used when calculating the fraction of a grid volume experiencing large-scale convection. This value is appropriate for highly soluble gases and aerosols but appears to be a factor of 3 too small for ${ }^{7} \mathrm{Be}$ [Brost et al., 1991; Liu et al., 2001].

[36] The reasonable agreement in the upper troposphere is significant because previous calculations driven by GEOS
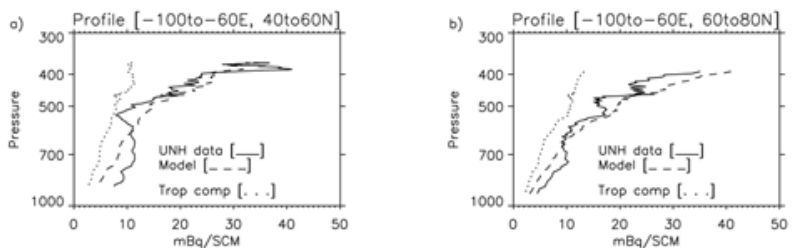

Figure 7. Vertical profiles of ${ }^{7} \mathrm{Be}$ mixing ratio for the southern (sampling latitudes $\leq 60^{\circ} \mathrm{N}$ ) (a) and northern (sampling latitudes $>60^{\circ} \mathrm{N}$ ) (b) portions of the TOPSE region. The mean profiles were obtained by applying a 25point smoother to the raw fields after weighting them by sampling time and sorting them by pressure. The mean profile calculated using measurements (model output) is shown with a solid (dashed) line. The mean profile of trop $-{ }^{7} \mathrm{Be}$ is shown with a dotted line. 

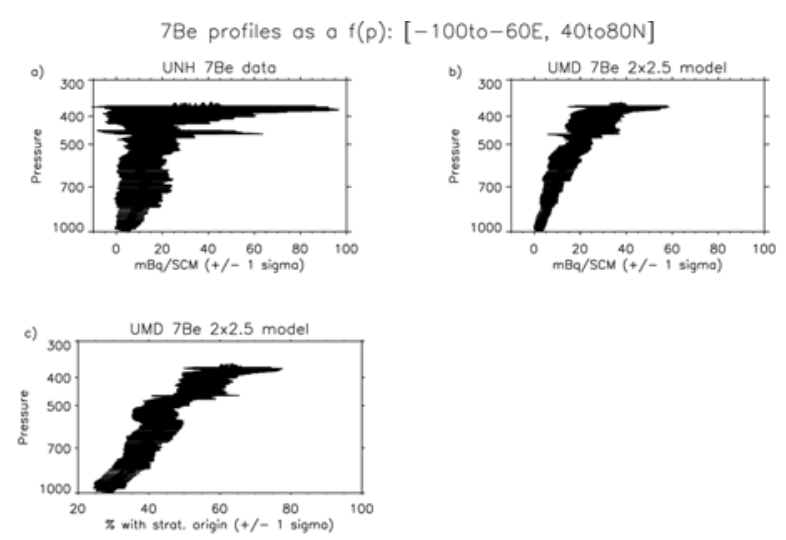

Figure 8. Vertical profiles of observed ${ }^{7} \mathrm{Be}(\mathrm{a})$, modelcalculated ${ }^{7} \mathrm{Be}(\mathrm{b})$, and percent of model-calculated ${ }^{7} \mathrm{Be}$ with a stratospheric source (c). The profiles were obtained by applying a 25-point smoother to the raw fields after sorting them by pressure. The standard deviation was calculated for each 25-point subset, and the mean $\pm 1 \sigma$ is shown.

DAS fields have overestimated net STE by a factor of $\sim 3$ [Bey et al., 2001; Liu et al., 2001]. The reasonable agreement is consistent with results obtained by Gettelman and Sobel [2000]. They found that Northern Hemisphere extratropical net winter cross-tropopause fluxes derived using GEOS-1 DAS fields differ from UKMO-based estimates by only $15 \%$. The main difference between this calculation and the calculations of Liu et al. and Bey et al. is the vertical grid. A sigma-pressure coordinate system was used for this simulation while a sigma coordinate system was used for the previous calculations. CTM-calculated STE may be extremely sensitive to the vertical coordinate.

[37] The variability of observed and model-calculated mixing ratios as a function of pressure is shown in Figures $8 \mathrm{a}$ and $8 \mathrm{~b}$, respectively. Model-calculated mixing ratios are less variable than observed, especially in the upper troposphere. Both the measurements and model output show a peak in variability in the upper troposphere. The variation of the model-calculated stratospheric component (the percent of total ${ }^{7} \mathrm{Be}$ with a stratospheric source) with pressure at the location of TOPSE measurements is shown in Figure 8c. It equals $25-30 \%$ near the surface and increases steadily with height reaching $40-45 \%$ by $650 \mathrm{hPa}$. The stratospheric component then remains steady to $\sim 475 \mathrm{hPa}$ before increasing rapidly and reaching $64 \%$ by $365 \mathrm{hPa}$.

\section{Evaluation of Seasonal Changes in $\mathrm{O}_{3}$ During the TOPSE Period}

[38] The evaluation of seasonal changes in $\mathrm{O}_{3}$ mixing ratios during the TOPSE period will be divided into four sections. In the first section, correlations between $\mathrm{O}_{3}$ and four stratospheric tracers (PV, model-calculated ${ }^{7} \mathrm{Be}$, measured ${ }^{7} \mathrm{Be}$, and $\mathrm{HNO}_{3}$ ) will be assessed using measurements and model output along TOPSE flight paths. In the second section, seasonal trends in $\mathrm{O}_{3},{ }^{7} \mathrm{Be}$, and $\mathrm{PV}$ will be estimated using measurements and model output along TOPSE flight paths. In the third section, the contributions of changes in mass convergence, scavenging, and net radio- active production to seasonal changes in ${ }^{7} \mathrm{Be}$ will be evaluated for the southern and northern portions of the TOPSE region. Implications for seasonal changes in $\mathrm{O}_{3}$ will be discussed in section 4 .

\subsection{Tracer-Tracer Correlations During TOPSE}

[39] Correlations between $\mathrm{O}_{3}$ and $\mathrm{PV}, \mathrm{O}_{3}$ and measured ${ }^{7} \mathrm{Be}, \mathrm{O}_{3}$ and model-calculated tot- ${ }^{7} \mathrm{Be}, \mathrm{O}_{3}$ and modelcalculated strat- ${ }^{7} \mathrm{Be}, \mathrm{O}_{3}$ and $\mathrm{HNO}_{3}$, and model-calculated ${ }^{7} \mathrm{Be}$ and $\mathrm{PV}$ are shown as a function of $\theta$ for sampling latitudes less than and greater than $60^{\circ} \mathrm{N}$ in Figures $9 \mathrm{a}$ and $9 \mathrm{~b}$, respectively. Only free troposphere data points are included. $\mathrm{O}_{3}$ is most highly correlated with ${ }^{7} \mathrm{Be}$. Correlations range from 0.7 to 0.9 in the upper troposphere to $0.5-$ 0.7 in the lower troposphere. The moderate correlations in the lower troposphere indicate that ${ }^{7} \mathrm{Be}$ retains some value as a tracer of stratospheric air even in the lower troposphere. Correlations between $\mathrm{O}_{3}$ and model-calculated ${ }^{7} \mathrm{Be}$ (both tot- ${ }^{7} \mathrm{Be}$ and strat- ${ }^{7} \mathrm{Be}$ ) differ by only a small amount from correlations between $\mathrm{O}_{3}$ and measured ${ }^{7} \mathrm{Be}$. Correlations between $\mathrm{PV}$ and ${ }^{7} \mathrm{Be}$ are slightly higher than correlations between $\mathrm{PV}$ and $\mathrm{O}_{3}$ throughout the troposphere. In both cases, correlations with PV decrease rapidly below $\sim 290 \mathrm{~K}$. Correlations between $\mathrm{O}_{3}$ and $\mathrm{HNO}_{3}$ also fall off rapidly with decreasing $\theta$. Clearly, the value of $\mathrm{PV}$ and $\mathrm{HNO}_{3}$ as stratospheric tracers decreases rapidly with decreasing $\theta$. The $\theta$ range for which PV is a useful tracer of stratospheric air can be seen in Figure 10. This figure shows the correlation between $\mathrm{PV}$ and model-calculated ${ }^{7} \mathrm{Be}$ within the TOPSE region $\left(100^{\circ}-60^{\circ} \mathrm{W}\right)$ as a function of $\theta$ and latitude. Correlation coefficients in the lower stratosphere and upper troposphere exceed 0.85 within $15 \mathrm{~K}$ of the tropopause. Correlations decrease rapidly in the midtropo-
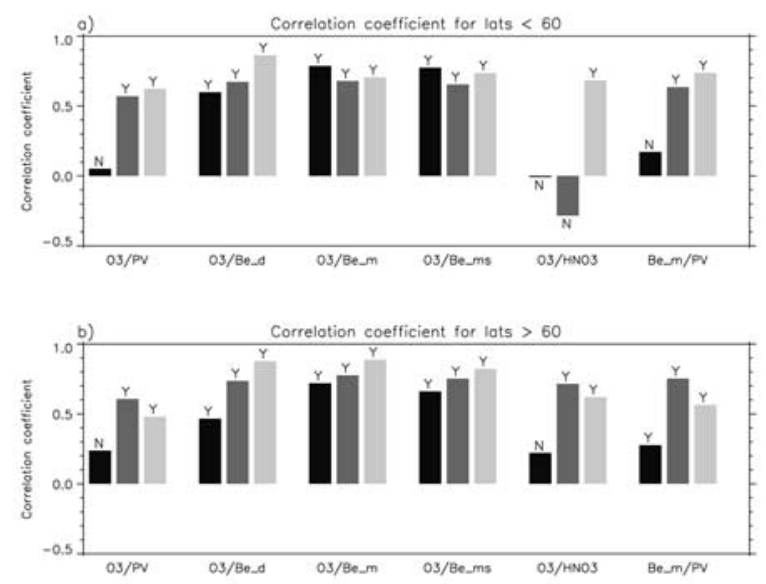

Figure 9. Correlation coefficient between $\mathrm{O}_{3}$ and $\mathrm{PV}, \mathrm{O}_{3}$ and measured ${ }^{7} \mathrm{Be}, \mathrm{O}_{3}$ and model-calculated tot- ${ }^{7} \mathrm{Be}, \mathrm{O}_{3}$ and model-calculated strat- ${ }^{7} \mathrm{Be}, \mathrm{O}_{3}$ and $\mathrm{HNO}_{3}$, and modelcalculated ${ }^{7} \mathrm{Be}$ and PV. Correlations are shown for $\theta<290 \mathrm{~K}$ (darkest bar), $290<\theta<300 \mathrm{~K}$ (dark bar), and $\theta>300 \mathrm{~K}$ (lightest bar). (a) Sampling latitudes $\leq 60^{\circ} \mathrm{N}$ and (b) sampling latitudes $>60^{\circ} \mathrm{N}$. The correlations in the southern (northern) portion of the TOPSE region were calculated using 34,40 , and $72(63,37$, and 28$)$ data points. Statistically significant (insignificant) correlations at a $95 \%$ confidence level are indicated with a $\mathrm{Y}(\mathrm{N})$. 


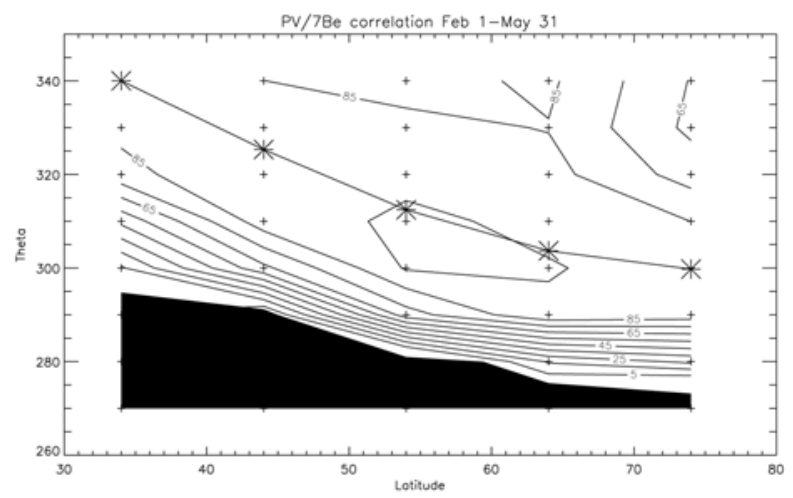

Figure 10. Mean $\mathrm{PV} /{ }^{7} \mathrm{Be}$ correlation for 1 February 2001 to 31 May 2001. The correlations were determined after mapping PV and ${ }^{7} \mathrm{Be}$ distributions at $0,6,12$, and $18 \mathrm{UT}$ onto eight $\theta$ surfaces between 270 and $340 \mathrm{~K}$. Areaweighted mean correlations for $100^{\circ}-60^{\circ} \mathrm{W}$ within five $10^{\circ}$ latitude bins between $30^{\circ} \mathrm{N}$ and $80^{\circ} \mathrm{N}$ are shown as a function of $\theta$. Regions where correlations are statistically insignificant at a 95\% confidence level and/or negative are shaded. The mean location of the tropopause within each latitude bin is shown with a large asterisk. Data point locations are shown with small "+'s".

sphere reaching $\sim 0$ for isentropic surfaces more than $40 \mathrm{~K}$ below the tropopause. PV, because it varies little in the lower troposphere, is a poor tracer of stratospheric air in the lower troposphere.

\subsection{Analysis of Observed Trends in $\mathrm{O}_{3}$ and ${ }^{7} \mathrm{Be}$}

[40] Before assessing trends, the 274 free troposphere data points (see section 3.2) were placed into six bins using three $\theta(\theta<290 \mathrm{~K}, 290 \mathrm{~K}<\theta<300 \mathrm{~K}$, and $\theta>300 \mathrm{~K})$ and two $\mathrm{PV}(\mathrm{PV}<0.75$ PVU, PV $>0.75$ PVU) categories. Binning tracers by potential temperature $(\theta)$ reduces meteorological variability associated with day-to-day changes in air mass, as air parcels remain on the same isentrope during the adiabatic ascent and descent associated with the passage of synoptic-scale features. Diabatic processes will change $\theta$; however, outside of regions of active convection, changes in $\theta$ following air parcels are typically less than $1 \mathrm{~K} \mathrm{~d}^{-1}$ [Holton, 1979]. Deployment-averaged values of $\mathrm{O}_{3}, \mathrm{PV}$, measured ${ }^{7} \mathrm{Be}$, and model-calculated ${ }^{7} \mathrm{Be}$ are shown for each of the bins in Figures 11, 12, and 13. Mean trends of $\mathrm{O}_{3}$ and $\mathrm{PV}$ are shown in Table 2. With one exception, $\mathrm{O}_{3}$ mixing ratios (see Figures 11a and 11c, 12a and 12c, and 13a and 13c) show a statistically significant increase with time during the TOPSE period. Increases of 4-7 ppbv month ${ }^{-1}$ are typical. $\mathrm{O}_{3}$ mixing ratios in the $\sim 295 \mathrm{~K} />0.75$ PVU bin do not show an increase with time as extensive sampling within the "tropospheric portion" of a 7 March fold caused $\mathrm{PV}$ values in this bin to decrease by $0.2 \mathrm{PVU}_{\text {month }^{-1}}$ (Figure 12c and Table 2). This sampling bias caused PV to decrease with time and $\mathrm{O}_{3}$ to remain steady during the TOPSE period.

[41] Trends in measured ${ }^{7} \mathrm{Be}$, model-calculated tot- ${ }^{7} \mathrm{Be}$, and model-calculated strat- ${ }^{7} \mathrm{Be}$ are shown in Figures $11 \mathrm{~b}$ and $11 \mathrm{~d}, 12 \mathrm{~b}$ and $12 \mathrm{~d}$, and $13 \mathrm{~b}$ and $13 \mathrm{~d}$ and in Table 3 . In most cases, agreement is reasonable in well-sampled bins where biases between model-calculated and measured mix-
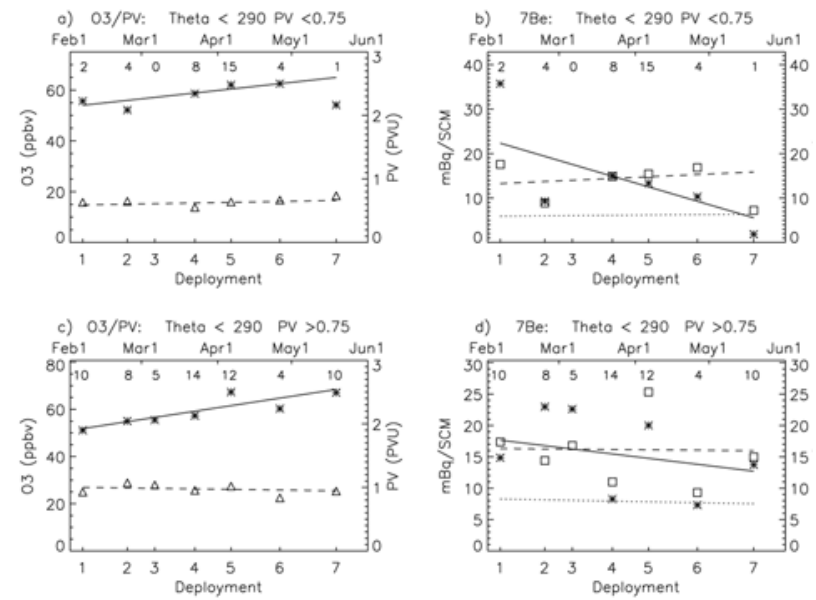

Figure 11. Mean $\mathrm{O}_{3}, \mathrm{PV}$, and measured and modelcalculated ${ }^{7} \mathrm{Be}$ for each deployment. Mean values during each deployment were calculated by weighting individual measurements during each deployment by the sampling length for ${ }^{7} \mathrm{Be}$. A weighted least squares line was fit to the deployment averages. The line was fit after weighting each deployment average by the number of samples during the deployment (given along the top of each plot). Only sampling points with $\theta<290 \mathrm{~K}$ are included. (a) $\mathrm{O}_{3}$ (*) and $\mathrm{PV}(\Delta)$ for sampling points with $\mathrm{PV}<0.75$ PVU. (b) measured ${ }^{7} \mathrm{Be}(*)$ and model-calculated ${ }^{7} \mathrm{Be}$ (boxes) for

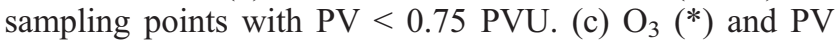
$(\Delta)$ for sampling points with PV $>0.75$ PVU. (d) measured $\left.{ }^{*}\right)$ and model-calculated (boxes)- ${ }^{7} \mathrm{Be}$ for sampling points with PV $>0.75$ PVU. Linear fits to deployment averages are shown with solid (measured $\mathrm{O}_{3}$ and ${ }^{7} \mathrm{Be}$ ) and dashed (PV and model-calculated ${ }^{7} \mathrm{Be}$ ) lines. A linear fit to deployment average strat- ${ }^{7} \mathrm{Be}$ is shown with a dotted line.

ing ratios are relatively small and poor in undersampled bins. For example, measurements show a large negative trend $\left(-34.9 \%\right.$ month $\left.^{-1}\right)$ in the $<290 \mathrm{~K} /<0.75$ PVU bin (Figure $11 \mathrm{~b})$ and a large positive trend $\left(20.7 \%\right.$ month $\left.^{-1}\right)$ in the $295 \mathrm{~K} /<0.75 \mathrm{PVU}$ bin (Figure 12b). Model-calculated
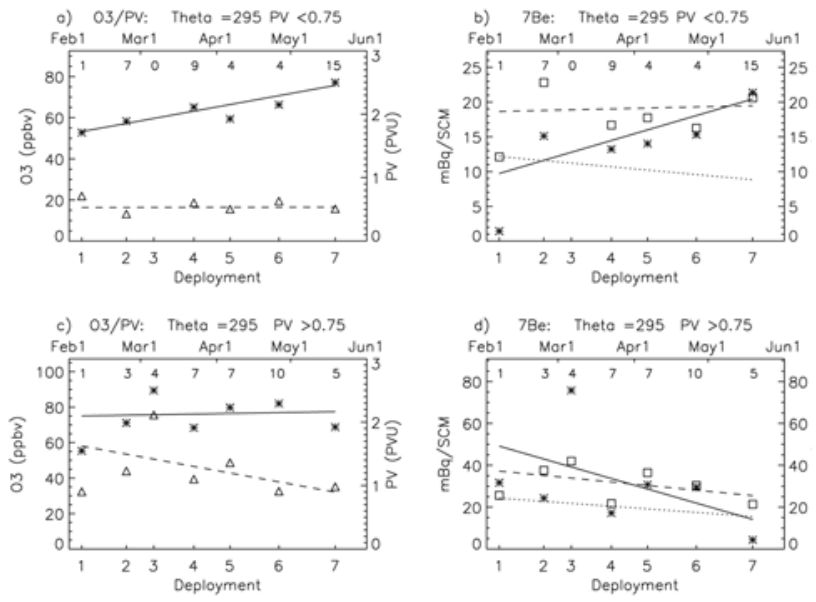

Figure 12. Same as Figure 11, but for sampling points with $290<\theta<300 \mathrm{~K}$. 

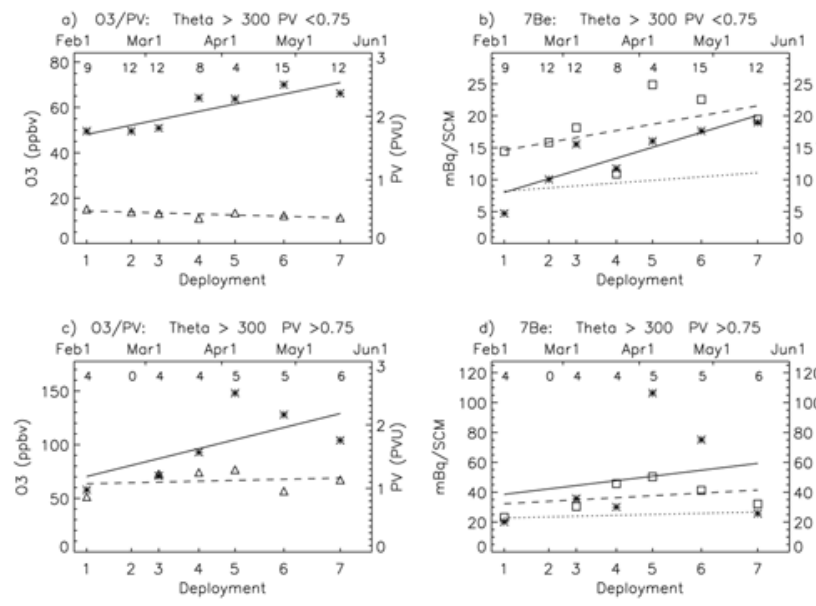

Figure 13. Same as Figure 11, but for sampling points with $\theta>300 \mathrm{~K}$.

trends in these bins are much smaller in magnitude. Inspection of Figures $11 \mathrm{~b}$ and $12 \mathrm{~b}$ indicates that these large "trends" are dependent upon the representativeness of one or two aerosol samples. For example, the large decrease in the $<290 \mathrm{~K} /<0.75$ PVU bin is driven by two high mixing ratios during deployment 1 and one low mixing ratio during deployment 7 (Figure 11b). $\mathrm{O}_{3}$ and ${ }^{7} \mathrm{Be}$ measurements in the $295 \mathrm{~K} /<0.75$ PVU bin show a similar pattern with an increase with time between deployments 1 and 7 . However, the increase observed in ${ }^{7} \mathrm{Be}$ may be overestimated as it is partially caused by one very low mixing ratio during deployment 1. Model-calculated mixing ratios may be more reliable than measured mixing ratios during "undersampled" deployments because model-calculated ${ }^{7} \mathrm{Be}$ mixing ratios are less variable than measured mixing ratios (see Figures $8 \mathrm{a}-8 \mathrm{c})$. Differences between model-calculated and measured trends are significantly smaller in other bins. Discounting the undersampled bins, ${ }^{7} \mathrm{Be}$ mixing ratios increase with time in the upper troposphere $(\theta>300 \mathrm{~K})$ and change little with time in the lower and middle troposphere.

[42] Deployment-averaged $\mathrm{O}_{3}$ and ${ }^{7} \mathrm{Be}$ mixing ratios were especially large for $\theta>300 \mathrm{~K}$ during flight 24 of deployment 5 (Figures 13c and 13d). This flight began in Broom-

Table 2. Trends in $\mathrm{O}_{3}$ and PV for Six Different $\theta / \mathrm{PV} \mathrm{Bins}^{\mathrm{a}}$

\begin{tabular}{cccccc}
\hline$\theta / \mathrm{PV}$ & & $\mathrm{O}_{3}(\%)$ & & $\mathrm{PV}$ & Npts \\
\hline$<290 /<0.75$ & 3.2 & 5.4 & $(\mathrm{Y})$ & 0.02 & 34 \\
$\sim 295 /<0.75$ & 6.5 & 10.1 & $(\mathrm{Y})$ & 0.00 & 40 \\
$>300 /<0.75$ & 6.6 & 11.3 & $(\mathrm{Y})$ & -0.03 & 72 \\
$<290 />0.75$ & 4.8 & 8.1 & $(\mathrm{Y})$ & -0.02 & 63 \\
$\sim 295 />0.75$ & 0.7 & 0.9 & $(\mathrm{~N})$ & -0.21 & 37 \\
$>300 />0.75$ & 17.1 & 17.0 & $(\mathrm{Y})$ & 0.03 & 28 \\
\hline
\end{tabular}

${ }^{\mathrm{a}}$ The $\theta / \mathrm{PV}$ bins $(\theta<290 \mathrm{~K}, 290 \mathrm{~K}<\theta<300 \mathrm{~K}, \theta>300 \mathrm{~K})$ and $\mathrm{PV}(\mathrm{PV}<$ 0.75 PVU, $\mathrm{PV}>0.75 \mathrm{PVU}$ ) are shown in column $1 . \mathrm{O}_{3}$ trends expressed in ppbv month ${ }^{-1}$ and $\%$ month $^{-1}$ are shown in columns 2 and 3. Statistically significant (insignificant) $\mathrm{O}_{3}$ trends at a 95\% confidence level are identified in column 4 with a $\mathrm{Y}(\mathrm{N})$. The significance tests assume a Student's t distribution with 5 or 6 degrees of freedom depending on the number of deployments with at least one sample in the bin. The PV trend in PVU month ${ }^{-1}$ is shown in column 5 . The number of data points in each bin (Npts) is shown in column 6.
Table 3. Trends in Measured- ${ }^{7} \mathrm{Be}$, Model-Calculated Tot- ${ }^{7} \mathrm{Be}$, and Model-Calculated Strat ${ }^{7}$ Be For Six Different $\theta /$ PV Bins ${ }^{a}$

\begin{tabular}{|c|c|c|c|c|c|}
\hline$\theta / \mathrm{PV}$ & & Be (Data) & Tot- $^{7}$ & ${ }^{7} \mathrm{Be}$ (Model) & Strat- ${ }^{7} \mathrm{Be}$ (Model) \\
\hline$<290 /<0.75$ & -4.9 & $-34.9 \%(\mathrm{Y})$ & 0.8 & $5.2 \%$ & $2.2 \%$ \\
\hline$\sim 295 /<0.75$ & 3.1 & $20.7 \% \quad(Y)$ & 0.2 & $1.3 \%$ & $-1.0 \quad-9.2 \% \quad(\mathrm{Y})$ \\
\hline$>300 /<0.75$ & 3.5 & $25.8 \% \quad(\mathrm{Y})$ & 2.0 & $11.3 \% \quad(\mathrm{Y})$ & $0.8 \quad 8.8 \% \quad(\mathrm{Y})$ \\
\hline$<290 />0.75$ & -1.4 & $-9.4 \% \quad(\mathrm{~N})$ & -0.1 & $-0.6 \% \quad(\mathrm{~N})$ & $-0.2 \quad-2.8 \% \quad(\mathrm{~N})$ \\
\hline$\sim 295 />0.75$ & -10.2 & $-31.0 \%(\mathrm{Y})$ & -3.4 & $-10.7 \%(\mathrm{Y})$ & $-2.5-12.6 \%(\mathrm{Y})$ \\
\hline$>300 />0.75$ & 6.0 & $12.2 \% \quad(\mathrm{~N})$ & 2.7 & $7.2 \% \quad(\mathrm{~N})$ & $1.2 \quad 4.6 \% \quad(\mathrm{~N})$ \\
\hline
\end{tabular}

field, $\mathrm{CO}$ and ended in Winnipeg, Manitoba. A curtain plot (not shown) for this flight indicated that several of the samples were taken within a tropopause fold. Only one of the samples was classified as stratospheric using the criteria described in section 3.2; however, three additional samples with elevated $\mathrm{O}_{3}$ and ${ }^{7} \mathrm{Be}$ had mean sampling pressures within $10 \mathrm{hPa}$ of the 6-hour average tropopause pressure. These samples could easily have been classified as stratospheric with a slightly more relaxed criteria. The sensitivity of trends to the tropopause definition is a concern and indicates that trends for PV $<0.75 \mathrm{PVU}$ are more reliable than trends for PV $>0.75$ PVU.

[43] For a given pressure level in the troposphere, mean values of $\theta$ decrease with increasing latitude (e.g., Figure 1). Therefore, upper tropospheric sampling bins contain more low latitude (latitudes $<60^{\circ} \mathrm{N}$ ) sampling points than lower tropospheric bins. The percent of samples collected at low latitudes is $25 \%$ for $\theta<290 \mathrm{~K}, 33 \%$ for $\theta \sim 295 \mathrm{~K}$, and $83 \%$ for $\theta>300 \mathrm{~K}$. Since ${ }^{7} \mathrm{Be}$ increases with time for $\theta>300 \mathrm{~K}$, it also increases with time in the southern portion of the TOPSE region. Changes in the northern portion of the TOPSE region are small (see section 5.3.1).

\subsection{Analysis of Model-Calculated ${ }^{7} \mathrm{Be}$ Trends in the Troposphere}

\subsubsection{Troposphere-Average Trends}

[44] In general, ${ }^{7} \mathrm{Be}$ mixing ratios along TOPSE flight paths increased with time in the upper troposphere and decreased or remained constant with time in the middle and lower troposphere. What changes were seen for the troposphere as a whole during the TOPSE period? Changes with time of troposphere-average model-calculated ${ }^{7} \mathrm{Be}$ mixing ratios are shown for the southern $\left(100^{\circ}-60^{\circ} \mathrm{W}, 40^{\circ}-60^{\circ} \mathrm{N}\right)$ and northern $\left(100^{\circ}-60^{\circ} \mathrm{W}, 60^{\circ}-80^{\circ} \mathrm{N}\right)$ portions of the TOPSE region in Figures $14 \mathrm{a}$ and $14 \mathrm{~b}$, respectively. Trends in trop- ${ }^{7} \mathrm{Be}$, strat- ${ }^{7} \mathrm{Be}$, and tot- ${ }^{7} \mathrm{Be}$ are also shown in Table 4 . The troposphere averages were obtained by weighting ${ }^{7} \mathrm{Be}$ mixing ratios at tropospheric grid volumes by the mass of each grid volume. Grid volumes are considered to be tropospheric if they reside entirely within the troposphere (i.e., if the pressure at the top of the volume is greater than the GEOS-3 DAS tropopause pressure at that grid point). The contributions of ${ }^{7} \mathrm{Be}$ with a tropospheric (trop- ${ }^{7} \mathrm{Be}$ ) and a stratospheric ( strat- $\left.^{7} \mathrm{Be}\right)$ source to the troposphere-average mixing ratios are also shown.

[45] Troposphere-average mixing ratios increased by $3.0 \%$ month $^{-1}$ in the southern portion of the region and by $1.3 \%$ month $^{-1}$ in the northern portion of the region. 

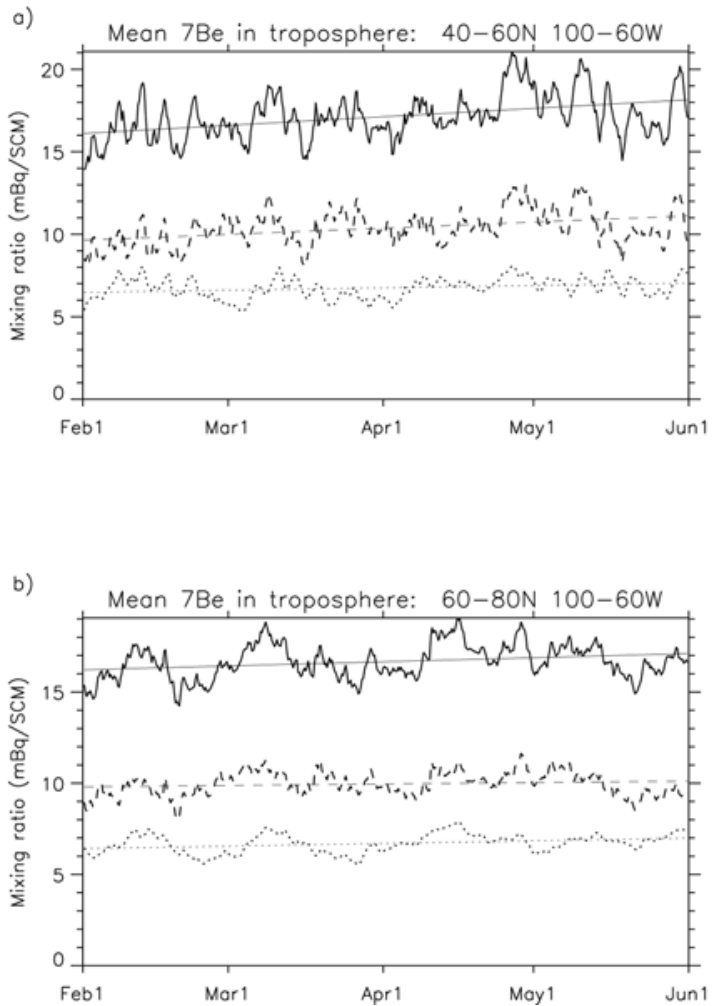

Figure 14. Time series of mean troposphere-average ${ }^{7} \mathrm{Be}$ mixing ratios for $100^{\circ}-60^{\circ} \mathrm{W}, 40^{\circ}-60^{\circ} \mathrm{N}$ (a) and $100^{\circ} 60^{\circ} \mathrm{W}, 60^{\circ} 80^{\circ} \mathrm{N}(\mathrm{b})$. The solid lines show total ${ }^{7} \mathrm{Be}$ mixing ratios. The dashed and dotted lines show the contribution from strat- ${ }^{7} \mathrm{Be}$ and trop- ${ }^{7} \mathrm{Be}$, respectively.

Both trop- ${ }^{7} \mathrm{Be}$ and strat- ${ }^{7} \mathrm{Be}$ increased with time; although, the relative increase of each component varied between the southern and northern portion of the TOPSE region. Trop- ${ }^{7} \mathrm{Be}$ mixing ratios increased by $2.1 \%$ in the southern portion of the region and by $2.2 \%$ in the northern portion of the region. Strat- ${ }^{7} \mathrm{Be}$ mixing ratios increased by $3.5 \%$ in the southern region but by only $0.8 \%$ in the northern region.

\subsubsection{Budget Analysis}

[46] Insight into the processes responsible for the changes with time of troposphere-average ${ }^{7} \mathrm{Be}$ mixing ratios in the southern and northern portions of the TOPSE region can be obtained by analyzing the ${ }^{7} \mathrm{Be}$ budget in each region. Changes in troposphere-average ${ }^{7} \mathrm{Be}$ mixing ratios due to mass convergence (advection and/or STE), imbalances between radioactive production and decay, and scavenging (both wet and dry) are shown for the southern and northern

Table 4. Trends ( $\%$ Month $^{-1}$ ) in Model-Calculated Tot $^{7} \mathrm{Be}$, Trop- ${ }^{7} \mathrm{Be}$, and Strat ${ }^{7} \mathrm{Be}$ for the Southern and Northern Portions of the TOPSE Region for 1 February to 31 May and 1 February to 30 April

\begin{tabular}{lcccccc}
\hline & \multicolumn{2}{c}{ February-May } & & \multicolumn{2}{c}{ February-April } \\
\cline { 2 - 3 } \cline { 6 - 6 } Field & South & North & & South & North \\
\hline Tot- ${ }^{7}$ Be & 3.0 & 1.3 & & 4.6 & 3.2 \\
Trop- ${ }^{7}$ Be & 2.1 & 2.2 & & 2.3 & 3.2 \\
Strat- ${ }^{7}$ Be & 3.5 & 0.8 & & 6.1 & 3.3 \\
\hline
\end{tabular}

portions of the TOPSE region in Figures $15 a-15 c$ and $16 a-$ $16 \mathrm{c}$, respectively.

[47] In the southern portion of the region, day-to-day fluctuations in troposphere-average ${ }^{7} \mathrm{Be}$ mixing ratios are dominated by changes in mass convergence during February and March and by a combination of changes in mass convergence and scavenging during April and May (Figure 15a). During February, trop- ${ }^{7} \mathrm{Be}$ decreases due to increases in mass divergence (due to net advection out of the region) and scavenging. Strat- ${ }^{7}$ Be mixing ratios remain steady as increases in STE overcome losses by scavenging and advection. Troposphere-average total ${ }^{7} \mathrm{Be}$ mixing ratios decrease slightly during this period due to the increase in scavenging. During March, advection continues to be a net sink of trop- ${ }^{7} \mathrm{Be}$ and presumably strat- ${ }^{7} \mathrm{Be}$ while STE continues to be a net source of strat- ${ }^{7} \mathrm{Be}$. However, neither process changes in strength during March and changes in ${ }^{7} \mathrm{Be}$ due to these processes are small. During April, net loss of trop- ${ }^{7} \mathrm{Be}$ via advection decreases rapidly; although, increases in trop- ${ }^{7} \mathrm{Be}$ are small because scavenging also increases rapidly during this period (see Figure 15b). Strat- ${ }^{7} \mathrm{Be}$ increases significantly during April. The increases
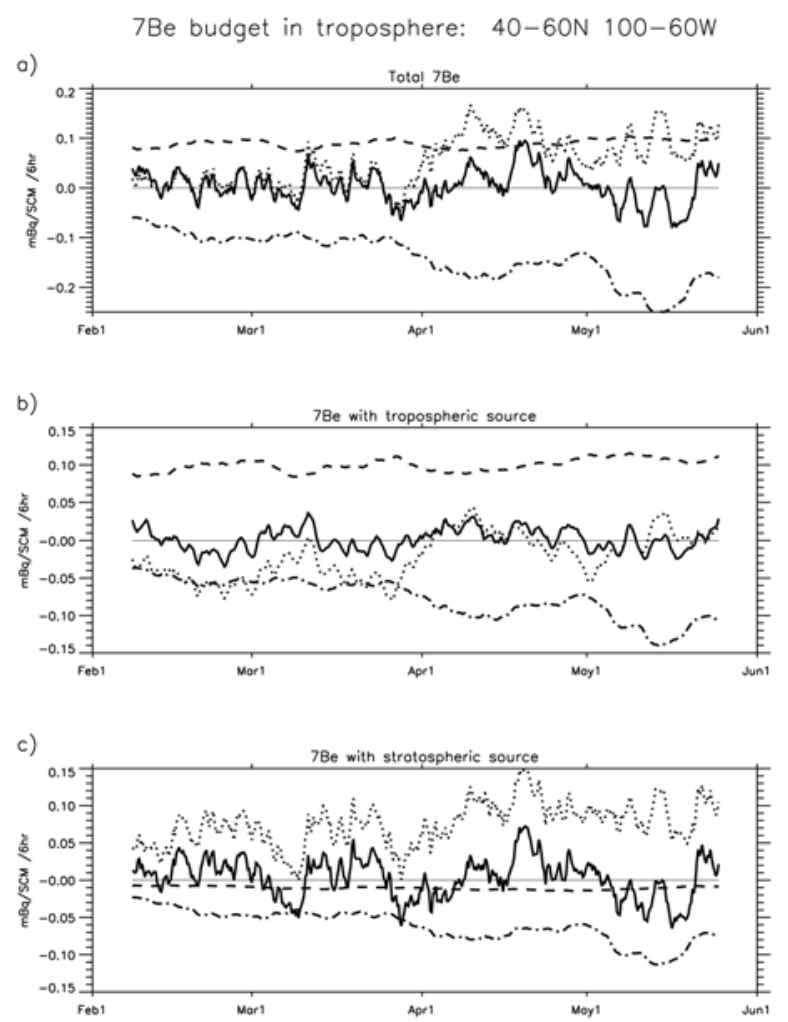

Figure 15. ${ }^{7} \mathrm{Be}$ budget within the troposphere for the southern portion of the TOPSE region. The thick solid line shows the change in mixing ratio during each 6-hour period due to all processes. The thick dotted, dashed, and dotdashed lines show the changes due to mass convergence, imbalances between radioactive production and decay, and scavenging. The zero line is shown with a thin solid line. In order to reduce noise, a boxcar smoother of width 57 (14 days) was applied to the time series before plotting. Because of the smoothing, only fields for 8 February to 24 May are shown. 

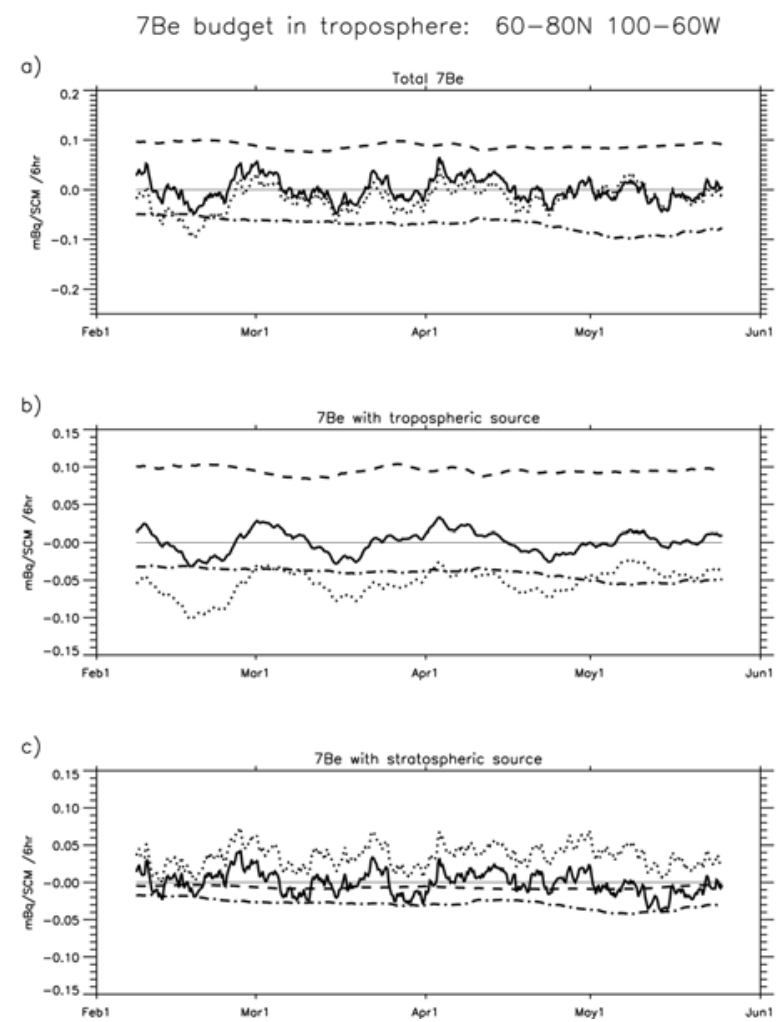

Figure 16. Same as Figure 15, but for northern portion of TOPSE region.

are most likely caused by increases in STE; although, increases in mass convergence due to horizontal advection also play a role. Mixing ratios of both trop- ${ }^{7} \mathrm{Be}$ and strat- ${ }^{7} \mathrm{Be}$ decrease during May as changes due to advection and/or STE level off while scavenging continues to increase.

[48] In the northern portion of the region, fluctuations in troposphere-average ${ }^{7} \mathrm{Be}$ mixing ratios are smaller and controlled by changes in mass convergence due to advection and/or STE. Seasonal trends are also smaller (see Table 4). In general, mass convergence leads to an increase in strat- ${ }^{7} \mathrm{Be}$ due to STE (Figure 16c) and a decrease in trop- ${ }^{7} \mathrm{Be}$ via advection out of the region or troposphereto-stratosphere exchange (Figure 16b). Contributions to strat- ${ }^{7}$ Be from STE (the dotted line in Figure 16c) increase during February remain constant during March and April and decrease slowly throughout much of May. Overall increases during the February-May period are small. Increases in trop- ${ }^{7} \mathrm{Be}$ exceed increases in strat- ${ }^{7} \mathrm{Be}$ (see Table 4) because the increase due to STE does not change significantly between mid-February and late May, while the net transport of trop- ${ }^{7} \mathrm{Be}$ out of the high latitude region decreases from February to May.

[49] Changes in troposphere-average ${ }^{7} \mathrm{Be}$ mixing ratios due to seasonal changes in the difference between radioactive production and decay are also shown in Figures 15 and 16. Radioactive production was held fixed throughout the simulation. However, the partitioning of the ${ }^{7} \mathrm{Be}$ source between the troposphere and stratosphere changes with time as the mean tropopause moves upward and poleward during the spring. This movement leads to an increase in the tropospheric component (Figure 15b) and a decrease in the stratospheric component (Figure $15 \mathrm{c}$ ). With the ${ }^{7} \mathrm{Be}$ source held fixed, seasonal increases in scavenging also lead to an imbalance between radioactive production and decay. Decay is suppressed and the net change in productiondecay during the TOPSE period is positive (Figure 15c). However, the overall contribution of imbalances between radioactive production and decay to the ${ }^{7} \mathrm{Be}$ trend is small.

\subsection{Implications for Seasonal Changes in $\mathbf{O}_{3}$}

[50] The differing temporal trends in ${ }^{7} \mathrm{Be}$ between the southern/high $\theta$ portion of the TOPSE region and the northern/low $\theta$ portion of the TOPSE region are consistent with the belief that changes in STE impact the tropospheric middleworld more than the underworld [Hoskins, 1991]. Potential temperature surfaces of less than $\sim 300 \mathrm{~K}$ are in the underworld throughout the TOPSE period (see Figure 1). It is also consistent with studies that show that total stratosphere-to-troposphere exchange falls off dramatically north of $50^{\circ} \mathrm{N}$ [Wernli and Bourqui, 2002]. The impact of seasonal increases in STE on the underworld is indirect and difficult to quantify with ${ }^{7} \mathrm{Be}$ since many different processes will affect its distribution before it reaches the underworld.

[51] $\mathrm{O}_{3}$ trends are positive throughout the troposphere but are larger in the tropospheric middleworld than in the underworld. The underworld trends may be partially caused by seasonal changes in STE; however, seasonal changes in photochemical processing and/or in the abundance of $\mathrm{O}_{3}$ precursors are much more likely explanations. Browell et al. [2002] estimated that seasonal changes in STE could explain less than $20 \%$ of the observed increase in $\mathrm{O}_{3}$ at latitudes poleward of $60^{\circ} \mathrm{N}$. Seasonal changes in STE are at least partially responsible for the springtime maxima in the tropospheric middleworld. The contribution is likely to decrease with time during the late spring after the springtime peak in STE. This decrease would be consistent with the decrease seen in tropospheric middleworld $\mathrm{O}_{3}$ and ${ }^{7} \mathrm{Be}$ mixing ratios between the sixth and seventh deployments (Figures 13a and 13b).

[52] The percent changes in strat- ${ }^{7} \mathrm{Be}$ shown in Tables 3 and 4 can be used to estimate the contribution of seasonal changes in STE to the springtime $\mathrm{O}_{3}$ maxima. This estimation assumes that $\mathrm{O}_{3}$ with a stratospheric source increases by the same percent as ${ }^{7} \mathrm{Be}$ with a stratospheric source (strat- ${ }^{7} \mathrm{Be}$ ). Assuming that this is the case, the increase in $\mathrm{O}_{3}$ with time $\left(\mathrm{dO}_{3} / \mathrm{dt}\right)$ can be calculated by multiplying the increase in strat- ${ }^{7} \mathrm{Be}$ with time $\left[\mathrm{d}\left(\right.\right.$ strat- $\left.\left.^{7} \mathrm{Be}\right) / \mathrm{dt}\right]$ by the fraction of total tropospheric $\mathrm{O}_{3}$ in the region of interest with a stratospheric source $\left[\mathrm{f}_{\text {strat }}\left(\mathrm{O}_{3}\right)\right]$ :

$$
\mathrm{dO}_{3} / \mathrm{dt}=\mathrm{d}\left(\text { strat }^{7} \mathrm{Be}\right) / \mathrm{dt}^{*} \mathrm{f}_{\text {strat }}\left(\mathrm{O}_{3}\right)
$$

For $\theta>300 \mathrm{~K}$ (the tropospheric middleworld), changes with time of strat ${ }^{7} \mathrm{Be}$ along TOPSE flight paths equals $4.6 \%$ $\left(\right.$ month $^{-1}$ ) for $\mathrm{PV}<0.75$ PVU and $8.8 \%$ for PV $>0.75 \mathrm{PVU}$ (see Table 3). Assuming $\mathrm{f}_{\text {strat }}\left(\mathrm{O}_{3}\right)$ equals 0.5 , these changes would result in a $2.3 \%$ (lower bound) to $4.4 \%$ increases in tropospheric middleworld $\mathrm{O}_{3}$. However, model-calculated trends of tot- ${ }^{7} \mathrm{Be}$ within the tropospheric middleworld $(7.2 \%$ and $11.3 \%$ ) are nearly a factor of 2 less than measured trends (12.2\% and 25.8\%) (see Table 3). If measured trends are accurate, increases in tropospheric middleworld $\mathrm{O}_{3}$ 
could be as large as $8.8 \%$ (upper bound). Nearly 50\% (72 of 146) of samples taken in the southern portion of the TOPSE region had values of $\theta$ exceeding $300 \mathrm{~K}$. Changes in strat- ${ }^{7} \mathrm{Be}$ with time in this region equaled $3.5 \%$ for 1 February to 31 May and $6.1 \%$ for 1 February to 30 April (see Table 4). These changes could lead to $1.7-6.1 \%$ increases in $\mathrm{O}_{3}$ within this region. The upper bound of $6.1 \%$ assumes that $\mathrm{f}_{\text {strat }}\left(\mathrm{O}_{3}\right)$ equals 0.5 for this region and that model-calculated trends are too low by a factor of 2 .

[53] For $\theta<300 \mathrm{~K}$ (the underworld), changes with time of strat- ${ }^{7} \mathrm{Be}$ along TOPSE flight paths are negative in bins where PV decreases with time and only slightly positive in bins where PV is constant or increasing slightly with time (see Table 3). The largest increase in strat- ${ }^{7} \mathrm{Be}$ with time is $2.2 \%(\theta<290 \mathrm{~K} ; \mathrm{PV}<0.75 \mathrm{PVU})$. This change could lead to $\mathrm{O}_{3}$ increases of $\sim 1 \%$. Measured ${ }^{7} \mathrm{Be}$ trends are not helpful in determining if $1 \%$ is a reasonable upper bound. They range from $-35 \%$ to $+20 \%$. Nearly $80 \%$ (100 of 128 ) of samples taken in the southern portion of the TOPSE region had values of $\theta$ less than $300 \mathrm{~K}$. Changes in strat- ${ }^{7} \mathrm{Be}$ with time in this region equaled $0.8 \%$ for 1 February to 31 May and $3.3 \%$ for 1 February to 30 April (see Table 4). These changes could lead to $0.4-1.7 \%$ (an upper bound) increases in $\mathrm{O}_{3}$ within this region.

[54] These estimates are highly uncertain for several reasons including the following: (1) Seasonal increases in scavenging affect ${ }^{7} \mathrm{Be}$ but not $\mathrm{O}_{3}$. Therefore, percent increases in strat- ${ }^{7} \mathrm{Be}$ may be less than percent increases in $\mathrm{O}_{3}$ with a stratospheric source. (2) Poleward and upward movement of the tropopause during spring decreases the source of strat ${ }^{7} \mathrm{Be}$. This effect is minor (see section 5.3.2) but does lead to a slight underestimation of the importance of seasonal increases in STE. (3) The fraction of $\mathrm{O}_{3}$ in the region of interest with a stratospheric source $\left[\mathrm{f}_{\text {strat }}\left(\mathrm{O}_{3}\right)\right]$ varies with time and location.

[55] This analysis indicates that seasonal changes in STE could lead to $2-9 \%$ increases in $\mathrm{O}_{3}$ within the tropospheric portion of the middleworld. These increases can be compared to measured increases of $10-15 \%$ (see Table 2). Therefore seasonal changes in STE explain $20-60 \%$ of observed $\mathrm{O}_{3}$ increases within the tropospheric portion of the middleworld. Increases in STE result in underworld $\mathrm{O}_{3}$ increases of less than $1.7 \%$. These increases can be compared to observed $\mathrm{O}_{3}$ increases in the underworld of 5$10 \%$. Therefore, seasonal changes in STE account for less than a third of observed increases in underworld $\mathrm{O}_{3}$.

\section{Summary}

[56] Measurements of tropospheric $\mathrm{O}_{3}$ between $30^{\circ} \mathrm{N}$ and $70^{\circ} \mathrm{N}$ show springtime maxima at remote locations. The contribution of seasonal changes in STE to the springtime $\mathrm{O}_{3}$ maxima was investigated using meteorological parameters derived from the GEOS-3 DAS, measurements from the TOPSE campaign, and the ${ }^{7} \mathrm{Be}$ distribution from a calculation with a 35 sigma-pressure layer version of the UMDCTM driven by GEOS-3 DAS fields.

[57] Separate calculations were performed for ${ }^{7} \mathrm{Be}$ with a tropospheric (trop- ${ }^{7} \mathrm{Be}$ ) and a stratospheric (strat- ${ }^{7} \mathrm{Be}$ ) source. Comparison of model-calculated ${ }^{7} \mathrm{Be}$ mixing ratios with measurements revealed that upper tropospheric mixing ratios were reasonable (albeit a bit high, especially in the northern part of the TOPSE region). The good agreement is significant because previous CTM calculations with a sigma vertical coordinate overestimated upper tropospheric mixing ratios by a factor of 3 . Lower tropospheric mixing ratios were too low, especially in the southern part of the TOPSE region, most likely due to an overestimation of scavenging. In general, temporal fluctuations in ${ }^{7} \mathrm{Be}$ mixing ratios were well captured even during constant altitude portions of TOPSE flights, although the magnitudes of the fluctuations were usually underestimated.

[58] Analysis of TOPSE $\mathrm{O}_{3}$ measurements as a function of $\theta$ indicated that $\mathrm{O}_{3}$ mixing ratios increased by $5-10 \%$ month $^{-1}$ for $\theta<300 \mathrm{~K}$ (the underworld) and by $10-15 \%$ month $^{-1}$ for $\theta>300 \mathrm{~K}$ (the tropospheric middleworld) between the first (5 February 2000) and last (18 May 2000) deployment.

[59] Model-calculated and measured trends in ${ }^{7} \mathrm{Be}$, a tracer of stratospheric air, were more variable during this period. In general, ${ }^{7} \mathrm{Be}$ mixing ratios decreased with time for $\theta<290 \mathrm{~K}$ and increased with time for $\theta>300 \mathrm{~K}$. Modelcalculated increases in the middleworld were approximately a factor of 2 less than measured increases. ${ }^{7} \mathrm{Be}$ and $\mathrm{O}_{3}$ trends also varied with latitude since nearly $50 \%$ of low latitude $\left(<60^{\circ} \mathrm{N}\right)$ samples were collected in the middleworld while nearly $80 \%$ of high latitude $\left(>60^{\circ} \mathrm{N}\right)$ samples were collected in the underworld. Model-calculated mean tropospheric ${ }^{7}$ Be mixing ratios increased by $3.0 \%$ month $^{-1}$ in the southern portion of the TOPSE region and by $1.3 \%$ month $^{-1}$ in the northern of the TOPSE region. The differing temporal trends in ${ }^{7} \mathrm{Be}$ between the southern/high $\theta$ portion of the TOPSE region and the northern/low $\theta$ portion of the TOPSE region are consistent with studies that indicate that changes in STE impact the tropospheric middleworld more than the underworld.

[60] Seasonal changes in advection and STE contributed to a $4.6-8.8 \%$ increase in model-calculated ${ }^{7} \mathrm{Be}$ with a stratospheric source (strat- ${ }^{7} \mathrm{Be}$ ) along TOPSE flight paths within the tropospheric middleworld. Increases in strat- ${ }^{7} \mathrm{Be}$ in the southern portion of the TOPSE region totaled $3.5 \%$. Changes in strat- ${ }^{7} \mathrm{Be}$ along TOPSE flight paths in the underworld were often negative and no larger than $2.2 \%$. Increases in strat- ${ }^{7} \mathrm{Be}$ within the northern portion of the TOPSE region totaled only $0.8 \%$. Assuming changes in $\mathrm{O}_{3}$ with a stratospheric source are the same as changes in ${ }^{7} \mathrm{Be}$ with a stratospheric source and that $50 \%$ of $\mathrm{O}_{3}$ in the region of interest was produced in the stratosphere, changes in STE explain $20-60 \%$ of $\mathrm{O}_{3}$ increases in the tropospheric middleworld and less than $33 \%$ of $\mathrm{O}_{3}$ increases in the underworld.

\section{Appendix}

[61] The ${ }^{7} \mathrm{Be}$ source used in this study was expressed in atoms ${ }^{7} \mathrm{Be} \mathrm{g}^{-1} \mathrm{~s}^{-1}$; however, ${ }^{7} \mathrm{Be}$ amounts are usually expressed in $\mathrm{mBq}$ or femto-Curies (fCi) per cubic meter at standard temperature and pressure (SCM). Milli-Becquerels and femto-Curies are measures of radioactive activity. One $\mathrm{mBq} \mathrm{SCM}^{-1}$ equals $27 \mathrm{fCi} \mathrm{SCM}^{-1}$. The activity of a radioactive sample can be defined in terms of Becquerels where a Becquerel equals one disintegration per second. The activity of ${ }^{7} \mathrm{Be}$ is proportional to its mixing ratio. It can be calculated by dividing the mixing ratio of ${ }^{7} \mathrm{Be}$ (atoms ${ }^{7} \mathrm{Be}$ $\left.\mathrm{g}^{-1}\right)$ by its lifetime with respect to radioactive decay $(76.88$ 
* 86,400 s). The mixing ratio of ${ }^{7} \mathrm{Be}$ in terms of $\mathrm{Bq} \mathrm{SCM}^{-1}$ can be obtained by dividing its activity by the density at STP $\left(1.293 \mathrm{~kg} \mathrm{~m}^{-3}\right)$. One Bq SCM ${ }^{-1}$ equals $1000 \mathrm{mBq}$ $\mathrm{SCM}^{-1}$. Therefore, $1 \mathrm{mBq} \mathrm{SCM}{ }^{-1}$ equals 0.1947 atoms ${ }^{7} \mathrm{Be}^{-1}$. Since $\mathrm{mBq} \mathrm{SCM}{ }^{-1}$ are proportional to mixing ratio, ${ }^{7} \mathrm{Be}$ activities when expressed in terms of $\mathrm{mBq}$ $\mathrm{SCM}^{-1}$ will be referred to as mixing ratios.

[62] Acknowledgments. The authors would like to thank Dorothy Koch for providing the ${ }^{7} \mathrm{Be}$ source distribution that was used in this paper, Louisa Emmons for creating the TOPSE data merges, Luca Cinquini for managing the many TOPSE data sets and presentations, and Eric Nash for giving his advice on equivalent latitude/potential temperature analysis. This material is based upon work supported by the National Science Foundation under grant 9910210. The opinions, findings, and conclusions or recommendations expressed in this material are those of the authors and do not necessarily reflect the views of the National Science Foundation.

\section{References}

Allen, D. J., R. B. Rood, A. M. Thompson, and R. D. Hudson, Threedimensional radon-222 calculations using assimilated meteorological data and a convective mixing algorithm, J. Geophys. Res., 101, 68716881, 1996a.

Allen, D. J., P. Kasibhatla, A. M. Thompson, R. B. Rood, B. G. Doddridge, K. E. Pickering, R. D. Hudson, and S.-J. Lin, Transport-induced interannual variability of carbon monoxide determined using a chemistry and transport model, J. Geophys. Res., 101, 28,655-28,669, 1996b.

Appenzeller, C., J. R. Holton, and K. H. Rosenlof, Seasonal variation of mass transport across the tropopause, J. Geophys. Res., 101, 15,071$15,078,1996$

Arakawa, A., and W. H. Schubert, Interaction of a cumulus cloud ensemble with the large-scale environment, part 1, J. Atmos. Sci., 31, 674-701, 1974.

Bamber, D. J., P. G. W. Healey, B. M. R. Jones, S. A. Penkett, A. F. Tuck, and G. Vaughan, Vertical profiles of tropospheric gases: Chemical consequences of stratospheric intrusions, Atmos. Environ., 18, 1759-1766, 1984.

Barrie, L. A., J. W. Bottenheim, R. C. Schnell, P. J. Crutzen, and R. A. Rasmussen, Ozone destruction and photochemical reactions at polar sunrise in the lower Arctic atmosphere, Nature, 334, 138-141, 1988.

Bey, I., D. J. Jacob, R. M. Yantosca, J. A. Logan, B. D. Field, A. M. Fiore, Q. Li, H. Y. Liu, L. J. Mickley, and M. G. Schultz, Global modeling of tropospheric chemistry with assimilated meteorology: Model description and evaluation, J. Geophys. Res., 106, 23,073-23,095, 2001.

Bloom, S. C., L. L. Takacs, A. M. DaSilva, and D. Ledvine, Data assimilation using incremental analysis updates, Mon. Weather Rev., 124, 12561271, 1996.

Brasseur, G. P., D. A. Hauglustaine, S. Walters, P. J. Rasch, J.-F. Müller, L. K. Emmons, and M. A. Carroll, MOZART, a global chemical transport model for ozone and related chemical tracers, 1, Model description, J. Geophys. Res., 103, 28,265-28,289, 1998.

Brewer, A. W., Evidence for a world circulation provided by the measurement of helium and water vapor distribution in the stratosphere, $Q . J . R$. Meteorol. Soc., 75, 351-363, 1949.

Brost, R. A., J. Feichter, and M. Heimann, Three-dimensional simulation of Be-7 in a global climate model, J. Geophys. Res., 96, 22,423-22,445, 1991.

Browell, E. W., et al., Ozone, aerosol, potential vorticity, and trace gas trends observed at high latitudes over North America from February to May 2000, J. Geophys. Res., 108, doi:10.1029/2001JD001390, in press, 2002.

Chen, P., Isentropic cross-tropopause mass exchange in the extratropics, J. Geophys. Res., 100, 16,661-16,673, 1995.

Chin, M., R. B. Rood, S.-J. Lin, J.-F. Müller, and A. M. Thompson, Atmospheric sulfur cycle simulated in the global model GOCART: Model description and global properties, J. Geophys. Res., 105, 24,67124,687, 2000 .

Cooper, O. R., J. L. Moody, J. C. Davenport, S. J. Oltmans, B. J. Johnson, X. Chen, P. B. Shepson, and J. T. Merrill, Influence of springtime weather systems on vertical ozone distributions over three North American sites, J. Geophys. Res., 103, 22,001-22,013, 1998.

Danielsen, E. F., Stratospheric-tropospheric exchange based upon radioactivity, ozone, and potential vorticity, J. Atmos. Sci., 25, 502-518, 1968.

Danielsen, E. F., and V. A. Mohnen, Project Dustorm Report: Ozone transport, in situ measurements, and meteorological analyses of tropopause folding, J. Geophys. Res., 82, 5867-5877, 1977.
Dibb, J. E., L. D. Meeker, R. C. Finkel, J. R. Southon, M. W. Caffee, and L. A. Barrie, Estimation of stratospheric input to the Arctic troposphere: 7-Be and 10-Be in aerosols, at Alert, Canada, J. Geophys. Res., 99, $12,855-12,864,1994$

Dibb, J. E., R. W. Talbot, E. M. Scheuer, G. L. Seid, DeBell, B. A. Lefer, and B. Ridley, Stratospheric influence on the northern North American free troposphere during TOPSE: Be-7 as a stratospheric tracer, J. Geophys. Res., 107, doi:10.1029/2001JD001347, in press, 2002.

Dobson, G. M. B., Origin and distribution of polyatomic molecules in the atmosphere, Proc. R. Soc. London, Ser. A, 236, 187-193, 1956.

Dutkiewicz, V. A., and L. Husain, Stratospheric and tropospheric components of ${ }^{7} \mathrm{Be}$ in surface air, J. Geophys. Res., 90, 5783-5788, 1985.

Ebel, A., H. Elbern, J. Hendricks, and R. Meyer, Stratosphere-troposphere exchange and its impact on the structure of the lower atmosphere, J. Geomagn. Geoelectr., 48, 135-144, 1996.

Elbern, H., J. Hendricks, and A. Ebel, A climatology of tropopause folds by global analyses, Theor. Appl. Climatol., 59, 181-200, 1998.

Feely, H. W., R. J. Larsen, and C. G. Sanderson, Factors that cause seasonal variations in beryllium-7 concentrations in surface air, J. Environ. Radioact., 9, 223-249, 1989.

Gettelman, A., and A. H. Sobel, Direct diagnoses of stratosphere-troposphere exchange, J. Atmos. Sci., 57, 3-16, 2000.

Giorgi, F., and W. L. Chameides, Rainout lifetimes of highly soluble aerosols and gases as inferred from simulations with a general circulation model, J. Geophys. Res., 91, 14,367-14,376, 1986.

Hoerling, M. P., T. K. Schaack, and A. J. Lenzen, Global objective tropopause analysis, Mon. Weather Rev., 119, 1816-1831, 1991.

Holton, J. R., An Introduction to Dynamic Meteorology, Academic, San Diego, Calif., 1979.

Holton, J. R., On the global exchange of mass between the stratosphere and troposphere, J. Atmos. Sci., 47, 392-395, 1990.

Holton, J. R., P. H. Haynes, M. E. McIntyre, A. R. Douglass, R. B. Rood, and L. Pfister, Stratosphere-troposphere exchange, Rev. Geophys., 33, 403-439, 1995

Hoskins, B. J., Towards a PV $-\theta$ view of the general circulation, Tellus, $43 A B, 27-35,1991$.

Huffman, G. J., R. F. Adler, B. Rudolf, U. Schneider, and P. R. Keehn, Global precipitation estimates based on a technique for combining satellite-based estimates, rain gauge analysis, and NWP model precipitation information, J. Clim., 8, 1284-1295, 1995.

Husain, L., P. E. Coffey, R. E. Meyers, and R. T. Cederwall, Ozone transport from stratosphere to troposphere, Geophys. Res. Lett., 4, 363-365, 1977.

Koch, D., and D. Rind, Beryllium 10/beryllium 7 as a tracer of stratospheric transport, J. Geophys. Res., 103, 3907-3917, 1998.

Koch, D., D. J. Jacob, and W. C. Graustein, Vertical transport of tropospheric aerosols as indicated by ${ }^{7} \mathrm{Be}$ and ${ }^{210} \mathrm{~Pb}$ in a chemical tracer model, J. Geophys. Res., 101, 18,651-18,666, 1996.

Lal, D., On the investigations of geophysical processes using cosmic ray produced radioactivity, in Earth Science and Meteoritics, compiled by J. Geiss and E. D. Goldberg, 312 pp., North-Holland, New York, 1963. Lal, D., and B. Peters, Cosmic ray produced radioactivity on the Earth, in Handbuch der Physik, 46/2, edited by K. Sitte, pp. 551-612, SpringerVerlag, New York, 1967.

Lawrence, M. G., and P. J. Crutzen, The impact of cloud particle gravitational settling on soluble trace gas distributions, Tellus, 50B, 263-289, 1998.

Lin, S. J., and R. B. Rood, Multidimensional flux form semi-Lagrangian transport schemes, Mon. Weather Rev., 124, 2046-2070, 1996.

Liu, H., D. J. Jacob, I. Bey, and R. M. Yantosca, Constraints from ${ }^{210} \mathrm{~Pb}$ and ${ }^{7} \mathrm{Be}$ on wet deposition and transport in a global three-dimensional chemical tracer model driven by assimilated meteorological fields, J. Geophys. Res., 106, 12,109-12,128, 2001.

Logan, J. A., Tropospheric ozone: Seasonal behavior, trends, and anthropogenic influence, J. Geophys. Res., 90, 10,463-10,482, 1985.

Monks, P. A., A review of the observations and origins of the spring ozone maximum, Atmos. Environ., 34, 3545-3561, 2000

Moody, J. L., J. C. Davenport, J. T. Merrill, S. J. Oltmans, D. D. Parrish, J. S. Holloway, H. Levy II, G. L. Forbes, M. Trainer, and M. Buhr, Meteorological mechanisms for transporting $\mathrm{O}_{3}$ over the western North Atlantic Ocean: A case study for August 24-29, 1993, J. Geophys. Res., 101, 29,213-29,227, 1996.

Moorthi, S., and M. J. Suarez, Relaxed Arakawa-Schubert: A parameterization of moist convection for general circulation models, Mon. Weather Rev., 120, 978-1002, 1992.

Morgenstern, O., and G. D. Carver, Comparison of cross-tropopause transport and ozone in the upper troposphere and lower stratosphere region, J. Geophys. Res., 106, 10,205-10,221, 2001.

Nash, E. R., P. A. Newman, J. E. Rosenfeld, and M. R. Schoeberl, An objective determination of the polar vortex using Ertel's potential vorticity, J. Geophys. Res., 101, 9471-9478, 1996. 
Oltmans, S. J., Surface ozone measurements in clean air, J. Geophys. Res., $86,1174-1180,1981$.

Penkett, S. A., and K. A. Brice, The spring maximum in photo-oxidants in the Northern Hemisphere troposphere and lower stratosphere, Nature, $319,655-675,1986$

Postel, G. A., and M. H. Hitchman, A climatology of Rossby wave breaking along the subtropical tropopause, J. Atmos. Sci., 56, 359$373,1999$.

Price, J. D., and G. Vaughan, Statistical studies of cut-off low systems, Ann. Geophys., 10, 96-102, 1992.

Rehfeld, S., and M. Heimann, Three dimensional atmospheric transport simulation of the radioactive tracers ${ }^{210} \mathrm{~Pb},{ }^{7} \mathrm{Be},{ }^{10} \mathrm{Be}$, and ${ }^{90} \mathrm{Sr}, J$. Geophys. Res., 100, 26,141-26,161, 1995.

Ridley, B., et al., Ozone depletion events observed in the high latitude surface layer during the TOPSE aircraft program, J. Geophys. Res., 107, doi:10.1029/2001JD001507, in press, 2002.

Roelofs, G.-J., and J. Lelieveld, Model study of the influence of crosstropopause $\mathrm{O}_{3}$ transports on tropospheric $\mathrm{O}_{3}$ levels, Tellus, 49B, 38$55,1997$.

Sander, R., and P. J. Crutzen, Model study indicating halogen activation and ozone destruction in polluted air masses transported to the sea, J. Geophys. Res., 101, 9121-9138, 1996.

Schubert, S. D., R. B. Rood, and J. Pfaendtner, An assimilated data set for earth science applications, Bull. Am. Meteorol. Soc., 74, 2331-2342, 1993.

Staley, D. O., Strontium-90 in surface air and the stratosphere: Some interpretations of the 1963-75 data, J. Atmos. Sci., 39, 1571-1590, 1982.
Susskind, J., P. Piraino, L. Rokke, L. Iredell, and A. Mehta, Characteristics of the TOVS Pathfinder Path A dataset, Bull. Am. Meteorol. Soc., 78, 1449-1472, 1997.

Talbot, R. W., et al., Reactive nitrogen budget during the NASA SONEX mission, Geophys. Res. Lett., 26, 3057-3060, 1999.

Wang, Y., D. J. Jacob, and J. A. Logan, Global simulation of tropospheric $\mathrm{O}_{3}-\mathrm{NO}_{\mathrm{x}}$ - hydrocarbon chemistry, 3, Origin of tropospheric ozone and effects of nonmethane hydrocarbons, J. Geophys. Res., 103, 10,75710,767, 1998.

Wei, M. Y., A new formulation of the exchange of mass and trace constituents between the stratosphere and the troposphere, J. Atmos. Sci., 44, 3079-3086, 1987.

Wernli, H., and M. Bourqui, A Lagrangian "1-year climatology" of (deep) cross-tropopause exchange in the extratropical Northern Hemisphere, J. Geophys. Res., 107, doi:10.1029/2001JD000812, 2002.

World Meteorological Organization, Atmospheric ozone 1985: Global Ozone Research and Monitoring Project, Rep. 16, 1094 pp., WMO, Geneva, Switzerland, 1996.

D. J. Allen and K. E. Pickering, Department of Meteorology, University of Maryland, College Park, MD, USA. (allen@atmos.umd.edu)

J. E. Dibb and R. W. Talbot, Institute for the Study of Earth, Oceans, and Space, University of New Hampshire, Durham, NH, USA.

B. Ridley, Atmospheric Chemistry Division, National Center for Atmospheric Research, Boulder, CO, USA. 